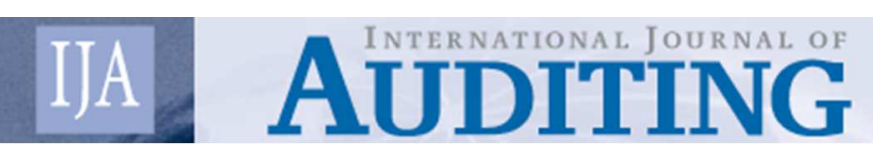

\title{
ADOPTION OF INTERNATIONAL STANDARDS ON AUDITING (ISA): DO INSTITUTIONAL FACTORS MATTER?
}

\begin{tabular}{|r|l|}
\hline Journal: & International Journal of Auditing \\
\hline Manuscript ID & IJA-2014-123.R2 \\
\hline Manuscript Type: & Original Article \\
\hline Keywords: & External Audit, Accountability, Auditing Standards \\
\hline \multicolumn{2}{|l}{} \\
\hline
\end{tabular}

SCHOLARONE ${ }^{\mathrm{m}}$

Manuscripts 


\begin{abstract}
Informed by the neo-institutional perspective, this study seeks for the first time to investigate empirically the determinants of ISA adoption and commitment to harmonisation on a crossnational basis ( 89 countries). The findings show that the protection of minority interests, regulatory enforcement, lenders/borrowers rights, foreign aid, prevalence of foreign ownership, educational attainment and particular forms of political system (level of democracy) prevailing in a country, are observed to be significant predictors of the extent of commitment to the adoption and harmonisation of ISAs. Our statistical analysis therefore suggests that coercive, mimetic and normative pressure have a significant impact on ISA adoption relative to economic (efficiency-led) factors. Our findings imply that current efforts by the International Federation of Accountants (IFAC) and other international agencies to implement ISAs need to recognise that a broad set of institutional factors, rather than narrow economic ones, are of relevance in the development of audit policymaking, practice and regulation worldwide.
\end{abstract}

Key words: International Standards on Auditing; Neo-institutional Theory; Accounting

\title{
Introduction
}

It is often claimed that the international harmonisation of accounting and auditing standards can be beneficial to the development of an effective and efficient global economy through the provision of relevant and credible accounting information to users and markets (Radebaugh \& Gray, 1997; Needles et al., 2002, Zeghal \& Mhedhbi, 2006; Murphy et al., 2008; Archambault \& Archambault, 2009; Leuz, 2010), culminating in significant attempts to bring convergence over the last decade (IASB, 2014). Yet, several studies have documented that there remains different levels of IFRS adoption and diffusion worldwide (Zeghal \& Mhedhbi, 2006; Leuz, 2010) arising from the different ways in which accounting developments interact with specific national economic, social, legal, cultural and political systems to generate particular accounting outcomes and/or practices. In this respect, both Zeghal \& Mhedhbi (2006) and Leuz (2010) express doubts on the accounting convergence 
process, whether in developed or developing economies. Contrastingly, there has been little research on the adoption and/or degree of commitment to auditing standards, and specifically the case of international standards on auditing (ISAs) (Needles et al., 2002; Ye \& Simunic, 2013; Simunic et al., 2013), in spite of the fact that ISAs are considered to be one of the key standards for sound financial systems by the Financial Stability Board (FSB) alongside IFRS. According to Simunic et al., (2013):

"Audits are performed to improve the validity and reliability of information produced in compliance with a set of accounting standards, and auditing standards provide a measure of audit quality and articulate the objectives to be achieved in an audit” (2013, p. 5). Auditing standards seek, for example, to codify aspects such as audit planning, audit engagement procedures, the collection and analysis of audit evidence, the review of internal control systems and the content of audit reports (Mennicken, 2008). Whilst the auditor still has flexibility in terms of how he/she executes the audit assignment (e.g. how much evidence is deemed to be sufficient), adherence to ISAs (or any other generally accepted auditing standards) confers credibility to the audit exercise and enables a third party (e.g. audit regulator; peer audit reviewer; parties in a litigation process) to infer upon an auditor's approach, completeness and consistency in carrying out an audit assignment. Furthermore, an audit firm claiming to offer a service in line with international standards can expect reputational and financial benefits in terms of high profile clients and premium fees.

Relatedly, Leuz (2010) argues that auditing is a part of the enforcement mechanism that ensures the accounting and reporting of information is appropriate to the needs of users and which moderates managerial discretion in the production of the financial statements. However, the potency of such enforcement depends partly on the way the standard is used by the auditor and the importance it has been assigned to in a particular jurisdictional context. In this respect, according to the International Federation of Accountants (IFAC), 126 countries have so far adopted ISAs using different bases (wholesale adoption by law, wholesale adoption by standard setter or partial adoption to meet country needs), which can be associated to the extent to which a country is committed to ISAs. A wholesale adoption of ISAs on a legal basis can be seen to be a clearer and stronger signal to an international and national 'audience' (including audit firms) as to the country's priority to the development of a 'weak or strong form of harmonisation' 1 of audit practice. Other forms of adoption admittedly communicate as well a commitment, inclusive of countries that have so far only

\footnotetext{
${ }^{1}$ A similar argument is put forward by Ben Othman and Kossentini (2015) whereby the authors assess IFRS adoption per country on the basis of a scale from 'weak' to 'strong' form (1-7) of harmonisation
} 
stated an intention 'on paper' to adopt ISAs, but our contention is that the different classifications of adoption represent varying forms of 'obligation' or engagement to ISAs. Relatedly, Simunic et al. (2013) contend that traditionally, how national auditing standards were developed and enforced tended to reflect a country's business environment and legal systems but recently, the authors assert that more countries have tended to adopt a more uniform set of standards, and in particular, it is predicted that ISAs will be adopted (with or without modifications) by countries with similar legal characteristics. However, to date, there has been no empirical validation of such predictions, and more importantly in our view, Simunic et al. (2003) does not consider the relevance other non-legal national characteristics that might lead to different forms of commitment to ISA adoption. The above discussion thus raises two related questions:

First, what are the factors that have influenced national ISA adoption and second, to what extent do these factors explain the different levels of commitment or engagement with ISA as defined by IFAC?

The motivations for this study are twofold. First, an understanding of the extent of commitment to ISA adoption cross-nationally and the determinants of such engagement can enlighten one's understanding of the national factors influencing the spread (or not) of global auditing standards. Recent work by Humphrey et al., (2009), Humphrey \& Loft (2013) and Simunic et al., (2013) have revealed how ISAs have gained prominence within the international financial architecture (2009, p. 811), which is controlled by the ISA issuer (International Federation of Accountants; IFAC), international financial regulators (such as IOSCO $^{\mathrm{i}}$ ) and large audit firms., Anecdotally, the World Bank's Reports on the Observance of Standards and Codes (ROSC) indicate that (1) many countries' auditing standards are not in line with ISAs, (2) even amongst those countries that have implemented ISAs, full compliance has not occurred mainly due to the lack of qualified professionals, adequate education and training, and enforcement (see also Kohler, 2009). Whilst a few country-level case studies (e.g. Brody et al., 2005; Dellaportas et al., 2008; Mennicken, 2008; Al-Awaqleh, 2010) have provided some insights for specific countries (e.g. US, Canada and China) and work by Humphrey et al. (2009) and Humphrey \& Loft (2013) have highlighted the positioning of ISAs and IFAC at the global level, there is correspondingly little empirical work that has considered the extent of harmonisation of ISAs cross-nationally (notable exception being Schockaert \& Houyoux, 2007, focusing on the EU). Second, our study seeks to complement the extant audit literature which has typically paid more attention to microlevel issues of audit independence, audit fees, audit committees and audit opinions (e.g. 
Bedard \& Gendron, 2010; Ghafran \& O'Sullivan, 2013). By providing evidence of the varying spread of, and commitment, to ISAs at a country level and the reasons thereof, we argue that such factors have a bearing on country or case studies which for instance examine the operation and effectiveness of ISA methodologies; at the level of audit firms and/or audit assignments.

Consequently, we develop an explanatory model which, in line with neo-institutional perspective, postulates that ISA adoption, in terms of the reported level of commitment to global harmonisation of auditing standards is associated to a number of social, cultural, political pressures which could be conceptualised as coercive, mimetic and normative forces, in addition to the typical economic (efficiency-led) pressures associated with greater calls for the harmonisation of auditing standards worldwide (e.g. stock market and economic development). Variables reflecting these institutional and efficiency-led pressures were considered and selected initially in line with prior studies (Needles et al., 2002; Zeghal \& Mhedhbi, 2006; Judge et al., 2010). However, given the possibility that a single proxy can hardly be expected to reflect all facets of coercive, mimetic and normative pressures respectively (as set out in Judge et al.'s (2010) work) and in light of the differences in the dynamics between commitment to ISA and IFRS adoption, we consider supplementary country-level data mainly from the Global Competitiveness Reports of the World Economic Forum, Economic Intelligence Unit and the World Bank's World Development Indicators. The archival data that is available for 89 countries over a four year period (2009-2012) forms the basis of the empirical analysis. Briefly, the paper's findings suggest that specific coercive, mimetic and normative pressures are associated to the extent of ISA adoption. Furthermore, different analytical approaches were used and a separate model was tested using the adoption of "Clarified ISAs" ii", to test the sensitivity of the results, and mindful of the argument that the dependent variable could be also seen as a categorical variable ${ }^{\mathrm{iii}}$. Fixed effect models (year fixed effects and country fixed effects) were also used to minimise both the effects of (i) omitted variable bias and (ii) endogeneity.

This study provides a pertinent empirical explanation of the institutional factors associated to the extent of the national commitment to ISA adoption and harmonisation. The findings are of relevance to policy-makers and advisers who are tasked with improving the quality of financial reporting worldwide and ensuring 'financial stability', the latter being an increasingly prominent agenda in the wake of several financial crises (Humphrey et al., 2009). Of note is the fact that IOSCO did not provide a clear endorsement of the 'clarified' ISAs in $2009^{\text {iv }}$. As reported by Humphrey \& Loft (2013), IOSCO merely 'encouraged' its members to 
accept audits performed and reported in accordance with ISAs whilst recognising that “....the decision whether to do so will depend on a number of factors and circumstances in their jurisdiction” (cited in Humphrey \& Loft, 2013, p. 335). Our study therefore sheds light on the nature of these factors and circumstances and why would particular countries signal different levels of commitment to ISAs. The remainder of the paper is structured as follows. A brief analysis of the state of ISAs worldwide is first presented followed by an explanation of the theoretical framework and the formulation of hypotheses. The data and methods are outlined followed by the findings, analysis and conclusions.

\section{Overview of International Standards on Auditing (ISAs)}

The increased initial attention to the state and development of ISAs has been often attributed to concerns about the quality of financial statements and auditing standards in the wake of the Asian economic crisis at the end of the 1990s and more recently, to the regulatory implications arising from the global financial crisis (Needles et al., 2002; Humphrey et al., 2009; Mennicken, 2008; Simunic et al., 2013). For instance, various international bodies (World Bank, International Monetary Fund) criticized large accounting firms for their apparent and uncritical acceptance of local GAAP when preparing financial statements, and highlighted the need for greater coordination between international and national auditing standards (Needles et al., 2002). In effect, a greater alignment between accounting and auditing developments was recommended to ensure that the international harmonisation agenda could deliver tangible outcomes for users, preparers and auditors (Radebaugh \& Gray, 1997). However, the paucity of studies on the implementation and harmonisation of auditing standards (e.g. Needles et al. 2002; Mennicken, 2008) relative to the large number of studies on accounting standards clearly reflected the priorities of academics, practitioners and policy makers.

Although auditing standards tend to be generally more prescriptive, process-oriented and involve a lower number of players (typically accounting firms, standard setters and international / national financial market regulators), Needles et al., (2002) observe that the process of international auditing harmonization has not been very successful (see also Kohler, 2009 in the case of the EU). The authors contend that the lag in the development and adoption of ISAs could be explained by (i) the need to resolve accounting issues (e.g. measurement) first before considering how to assess the implementation of these accounting issues by companies, (ii) the need to initially legislate on accounting and auditing matters to provide the necessary legal backing for external audits and financial statements, but a lag 
may be due to the inherent slowness of legislative processes, (iii) the influence of large accounting firms which have historically seen themselves as operating in a self-regulatory environment and hence not keen to embrace externally defined standards of practice ${ }^{\mathrm{v}}$, (iv) the resistance by local regulators to ISAs since the use of local auditing standards allowed them to have some control over the audit process, and (v) the low level of professional education and training in accounting which may impact on the quality of the auditing function in some countries. Needles et al., (2002) argue the above factors can be empirically tested but does not rely on a theoretical framework to justify the selection and relative importance of these factors. A common thread from Needles et al.'s, (2002) discussion suggests that the extent of commitment to ISAs may be dependent on how the accounting profession and accounting standards first 'bed in' in the relevant jurisdiction and secondly on how regulators will (if at all) handle enforcement and compliance.

Contemporary evidence on the extent of ISA implementation and the implications thereof has been gradually emerging over the last decade. The initial findings originate from the World Bank Reports on Observance of Standards and Codes (ROSCs 2003 to 2010) which provide narratives on the status and operation of auditing standards ( $w w w$. worldbank.org/ifa/rosc_aa.html.). In particular, the reports reveal that in many countries, local auditing standards have not been harmonised in line with ISAs. In some other countries ISAs are required by law signalling greater commitment but yet evidence shows that auditing processes do not fully comply with the standards. Table 1 summarises the findings from a number of countries ${ }^{\mathrm{vi}}$. These issues have also been seen relevant to the EU bloc (Kohler, 2009) and have been acknowledged as part of attempts to improve the global 'financial architecture' in the aftermath of the recent financial crisis (Ojo, 2010; Humphrey et al., 2009). Fraser (2010) is, however, particularly critical of the absence of a coherent approach to ISA adoption within the EU. At one level, there appears to be no major 'public' opposition to the need for the global harmonisation of auditing standards, but yet the extent of commitment at the national level remains problematic and is highlighted in the various country Statements of Membership Obligations (SMO) reports filed with IFAC (elaborated in subsequent sections). The continued variation in the extent of commitment to ISA harmonisation thus reveals the different outcomes and decisions reached by national policy makers on the suitability of ISAs for their jurisdictions.

\section{INSERT TABLE 1 ABOUT HERE}


In this stream of research, there have been very few in-depth investigations of the 'practice' of ISAs at the national level. Mennicken (2008) provides an extensive case study of how a leading Russian audit firm sought to adopt international auditing standards. In this respect, the author highlights the strong effect of the historical, social and political context of Russia, particularly in terms of accounting practice being primarily focused on tax rules and complying with government decrees. Mennicken's (2008) work underlines the point that a commitment to ISA adoption is expected to differ depending on the country's political, economic and social context.

Simunic et al. (2013) work seek to model the impact of ISA adoption on audit quality given a country's legal liability regime and concludes that there cannot be an optimal level for the adoption of ISAs worldwide unless there is also uniformity in the legal regimes of these countries. Hence, for countries where local legislation is weak and poorly enforced, compliance with ISAs could be well lead to a fall in audit quality. Whilst we do agree with Simunic et al.'s (2013) arguments, we contend that the cost-benefit analysis subsumed within this legal perspective a rather narrow interpretation of the relevance of social and political issues. In other words, the legal implications identified by Simunic et al., (2013) only emphasise the financial and economic consequence and do not explicitly consider that the effects of a legal regime may need to be analysed in the presence of other social and political factors pertaining to the jurisdiction. In contrast, other country studies (e.g. Al-Awaqleh, 2010; Brody et al., 2005) provide an account of some of the national difficulties in adopting ISAs but provide limited theoretically-informed analysis of the factors leading to the extent of adoption to, and harmonisation with, ISAs.

In conclusion to this section, there is a scant body of work on the dissemination of ISAs worldwide and why countries adopt ISAs at a particular level of 'commitment' (e.g. adoption by law, adoption using standard-setters, modified adoption). Whilst underlining the spread of ISA adoption worldwide, most authors - whether from an academic, professional or policy-making perspective - qualify their assessments of 'adoption' by referring to the moderating effects of institutional factors, and except for the notable case of Mennicken (2008), previous ISA studies have not been informed by an explicit theoretical framework. In this regard, our argument is that the level of commitment to, and adoption of, any professional standards of practice, either developed at national or international level, is influenced by the institutional environment (Nobes, 1998; Collier, 2002; Guler et al., 2002; Touron, 2005; Judge et al., 2010; Aguilera \& Cuervo-Cazzura, 2009; Leuz, 2010). Political, 
economic, cultural and social factors influence organisations and actors within a national setting country and these institutional pressures may construe why one country may either imitate (or not) other countries (as e.g. trading partner or related via colonial heritage, religious (and/or ethnic) affiliation, geographical proximity, and/or similar political systems/ideologies). Admittedly, efficiency motives (i.e. adoption of the standards on the grounds of functional and economic outcomes) can also explain a commitment to adopt (Simunic et al., 2013) but neo-institutional explanations have generally been found to be also relevant in similar cross-country studies of adoption or commitment to international practices such as corporate governance codes and IFRS (e.g. Aguilera \& Cuervo-Cazurra, 2004). More generally, the accounting literature has developed a body of evidence whereby motivations for accounting change, harmonisation and developments in accounting practice have been associated to diverse country-level factors (e.g. Ben Othman and Kossentini, 2015). In light of the nature of the practice (ISAs), a neo-institutional perspective provides the underpinning for our hypotheses.

\section{Theory and hypothesis development}

The neo-institutional perspective is based on the premise that organisations respond to pressures from their institutional environments and adopt structures and/or procedures that are socially accepted as being the appropriate organisational choice (Meyer \& Rowan, 1977; DiMaggio \& Powell, 1983 in Carpenter and Feroz, 2001). Tuttle \& Dillard (2007) and Judge et al. (2010) have relied on this framework in financial accounting research and other IFRSrelated studies, whilst not explicitly adopting a neo-institutional framework, have explored the empirical relevance of a range of institutional-led factors (e.g. Zaghal \& Mhedbhi, 2006; Archambault \& Archambault, 2009; Gordon et al., 2012) .

Using a hierarchy of institutional influence, Scott (2001) explains three different levels of institutional pressures. First the higher level environment affects the lower level institutions. He argues that higher level institutions (e.g. societal and global) formally propose models and standards which form and restrain actions at lower levels. At the second level there are the organisational governance structures which comprise of organisational field and the organisations themselves. An organisation field comprises of organisations in the same area of services such as the audit profession together with other organisations and constituencies which influence their performance such as accountants, bankers, insurers, 
regulators and the public. Scott (1987) further argues that organisations conform to institutional pressures for change due to the fact that they are rewarded for doing so through increased legitimacy, resources and survival capabilities. Organisations may react differently because they vary by size, culture, structures and management style. All these influence and are influenced by their organisational field and institutional environments. At the lower level are the individuals or groups who are influenced by the first two levels. Carpenter \& Feroz (2001) suggest that a State's decision to commit or adopt generally accepted accounting principles (GAAP) can be influenced at individual, organisational and organisational field level. At the individual level, the pressures are through key decision-makers' norms, values and unconscious conformity to traditions, at organisational level by shared belief systems, power and politics and at organisational field level through regulatory pressures, public pressures and the accounting profession's norms and values. In a similar vein therefore, a country's decision to engage with ISAs at different levels of commitment (or harmonisation) can also be influenced at individual, organisational and organisational field level.

The forces and/ or pressures within the three levels of analysis proposed by Scott (2001) align with DiMaggio \& Powell's (1983) explanation of the homogenisation process of organisation. DiMaggio \& Powell (1983) describe this process as isomorphism i.e. a process which causes one unit from a population to look like other units in the same population operating in similar environmental condition. They identify two categories of isomorphism, namely: competitive and institutional and further sub-divide institutional isomorphism into three types: coercive, mimetic and normative isomorphism. This paper focuses on the three types of isomorphism. Similarly, Judge et al., (2010) adopt the three types of isomorphism in a cross-national study seeking to explain national IFRS adoption in 132 countries. They argue that the extent of IFRS adoption (as defined by Deloitte, 2008) is the result of coercive, mimetic and normative pressures (explained further below). They identify one variable for each type of institutional pressure, respectively foreign aid, important penetration and educational level, and find all three variables to be significant in the presence of two control variables (market capitalisation and GDP growth). The authors also find that the traditional cultural variables (Hofstede, 1984) and securities law (La Porta et al., 2006) are not significant in explaining the extent to which a country will adopt IFRS.

Coercive isomorphism stems from resource dependence and legitimacy concerns (DiMaggio and Powell, 1983). The authors argue that this type of isomorphism can originate from the highest level institutions, which can influence the structures and actions of social and economic actors. An example of a powerful institution is the State (Scott, 1995) because 
organisations within a country are influenced by rules and regulations institutionalised and legitimised by the State (Meyer \& Rowan, 1977). Organisations can also be required to commit to different levels of ISA harmonisation due to legislation, rules, and regulations set up by the stock market regulators, competition or sector-based bodies (e.g. central banks), and other regulatory agencies, such as accounting and audit standard setting institutions. However, the 'potency' of these coercive mechanisms may differ in different institutional contexts by virtue of the extent to which a threat to legitimacy would ensue and the penalties faced by organisations for not signalling a sufficient level of adoption or commitment to harmonisation. At the same time, certain forms of legal systems can hamper the incorporation of international standards in local regulations. For instance, both Aguilera \& Cuervo-Cazurra (2004) and Zattoni \& Cuomo (2008) examine elements of the legal system (common law vs. civil law, extent of shareholder protection rights) on the country's decision to issue corporate governance (CG) codes. In contexts characterised by a common-law system and a lack of shareholder protection rights, it is observed that CG codes were issued faster compared to other countries exhibiting a civil-law system and stronger shareholder rights. Whilst corporate governance codes might be conceived as a substitutive mechanism to counterbalance generally weak or ineffective shareholder protection legislation, it may be argued that the adoption of ISA standards is a rather complementary mechanism in ensuring the quality of financial statements. Overall, one might expect that extent of commitment to ISA adoption and harmonisation would be higher in national contexts where minority interests are more protected. Therefore, we hypothesise that

H1: There is a positive relationship between the extent to which minority interests are protected and the extent of commitment to ISA adoption and harmonisation. .

A key insight from the various studies commenting on the spread of ISAs (Needles et al., 2002; Humphrey et al., 2009; Humphrey \& Loft, 2013; Simunic et al., 2013) relates to the issue of enforcement in national settings. ISAs may be developed and improved at the global level by international institutions (IOSCO, IFAC, global accounting firms) but in practice, how and to what extent accounting firms implement international auditing standards is left to local (or foreign) professional bodies and regulatory agencies. Whilst there has been recent attempts (e.g. refer to Humphrey et al., 2013) to assist national structures (typically involving an audit regulator, national professional associations and other State regulators), there are, however, generic issues relating to the power, authority, competence and resource attributed to enforcement agencies. As argued by Simunic et al., (2013), adopting a set of standards 
without a proper legal enforcement system will not necessarily improve audit quality. Similarly, Kolk \& Perego (2010) contend that the independent audit function “...facilitates contracting by reducing information asymmetry and monitoring the performance of the contracting parties" (2010, p. 186) but this is conditional upon a robust legal and enforcement infrastructure. We, therefore, argue that the extent of regulatory enforcement may influence the extent of commitment to ISA adoption and harmonisation in a given jurisdiction. Hence we propose the following hypothesis,

H2: There is a positive relationship between the extent of regulatory enforcement and the extent of commitment to ISA adoption and harmonisation.

La Porta et al., (1998) contend that lenders rights are more complex than shareholder rights for two reasons. First there are creditors with overriding rights (senior secured creditors) on other creditors with lesser rights (junior creditors). Senior creditors have the right to repossess and then liquidate or keep collateral when a loan is in default (Hart, 1995). However, some jurisdictions make it difficult for those creditors to repossess because this entices the liquidation of the firms whereas in some other countries creditors do have the power to repossess by exercising their rights on the collaterals (La Porta et al., 1998). In either case, lenders or creditors represent a critical constituency for the audit profession in terms of the formers' reliance on audited financial information and their ability to dictate terms in lending agreements, inclusive of the identity of the external auditors to be appointed and the basis upon which the accounts and its audit ought to be carried out. Interestingly, studies relating to the adoption of IFRS do not highlight the relevance of lenders'/borrowers' rights and focus instead on the investors' or stock market characteristics and/or assume that the legal system is consistent in terms of the protection of minority interests, shareholders and lenders. Contrastingly, we propose that:

H3: There is a positive relationship between lenders and borrowers rights and the extent of commitment to ISA adoption and harmonisation.

Institutions such as the International Monetary Fund (IMF) or European Union (EU) can also pressure a country or organisation in a country to conform to international standards. This is evidenced in the recommendations formulated within most World Bank ROSC reports, and such recommendations are often linked to the setting of local professional accounting bodies and the establishment of a local audit regulator. The adoption of 'best' and 'international practices' is often contained within the so-called loan 'conditionality' 
agreements enacted between supra-national institutions and the governments of developing countries (e.g. Neu \& Ocampo, 2007). Especially in the case where a country faces financial distress and where the IMF has provided foreign aid to countries it strongly recommends them to also adopt IFRS, corporate governance codes and ISAs. Hassan (2008) suggests that coercive pressures may thus arise from foreign aid agreements whereby international institutions can influence a country to adopt 'best practice standards' (e.g. refer to Ashraf and Ghani, 2005). Judge et al., (2010) also concluded that the foreign aid indicator aptly proxies for the extent to which nation states may be vulnerable to a variety of outside pressures. Whilst foreign aid may be objectively seen as being the outcome of a development policy, we would argue that a foreign aid 'relationship' incorporates as well, if not more prominently, a political and diplomatic dimension, whereby the donor may be able to exercise some power and control over the national policies, actions and decisions of the aid recipient. In a similar vein, Zeghel \& Mhedhbi (2006) contend that the degree of economic openness towards large foreign government institutions such as “....world financial institutions” (p.377) can be a relevant variable but the authors did not find significant results to support their claim of the influence of economic openness on ISA adoption levels (see also results from Archambault \& Archambault, 2009). Notwithstanding the above, the following hypothesis is proposed:

H4: There is a positive relationship between foreign aid and the extent of commitment to ISA adoption and harmonisation.

Mimetic isomorphism occurs when social actors mimic the behaviour of other social actors who are perceived as successful in a bid to improve their own legitimacy and acceptance (DiMaggio \& Powell, 1983). Mimetic isomorphism is considered as a principal factor leading to homogenisation (Mizruchi \& Fein, 1999). In this respect, a country's commitment to ISA adoption and harmonisation could be influenced by the presence of foreign commercial partners. Wei et al., (2001) state that the more open a country is to foreign trade and outside investment, the more it is exposed to 'international best practices' and consequently may be more inclined to signal a commitment to ISA adoption and harmonisation to gain greater legitimacy in the global market. For example, Mennicken's (2008) study does associate the Russian firm's enthusiasm in implementing ISAs with an ambition to become part of the group of internationally recognised audit firms and be able to serve the international audit market. Other accounting studies used foreign direct investment, foreign market and colonial influence as a predictor of IFRS adoption (Nobes, 1998; Guler et al., 2002). Rodrigues \& Craig (2006), cited in Judge et al. (2010), suggest that social systems 
often emulate the success of others and that this could influence the accounting and auditing harmonisation process. Finally, Aguilera \& Cuervo-Cazurra (2004) consider how foreign trade and investment could reflect the degree to which certain countries are integrated in the world economy. By extension, the degree of integration might explain the country's decision to adopt corporate governance codes not only because the code's implementation can have instrumental consequences (better competitiveness, better access to finance) but also provide legitimating outcomes for the country as whole (e.g. to be seen as 'modern' and 'professional' economy). Similarly, Archambault \& Archambault (2009) find support for the influence of net imports on the level of IFRS adoption but this finding was not confirmed by Zeghal \& Mhedhbi (2006). It could be argued that foreign ownership and import penetration represent the 'conduits' through which national structures gain greater exposure and share information on the harmonisation of 'best practices' (Wei et al., 2001), thereby generating mimetic behaviours. In light of the above discussion, it is therefore hypothesised that:

H5: There is a positive relationship between the prevalence of foreign ownership of businesses in a country and the extent of commitment to ISA adoption and harmonisation

H6: There is a positive relationship between the extent of import penetration of a country and the extent of commitment to ISA adoption and harmonisation.

Normative isomorphism refers to the collective values that entail conformity of thought and deed within institutional environments (Di Maggio \& Powell, 1983). Two key institutions through which collective values and conformity of thought and deed could be enacted are the educational system and the political regime/system of the country. Many studies in accounting have demonstrated how the political systems and educational level of a country can heighten or stifle accounting development (see Nobes, 1983; Gernon et al., 1987; Gray, 1988; Zhegal \& Mhdehbi, 2006; Archambault \& Archambault, 2009). For example, Zhegal \& Mhdehbi, (2006) suggest that modern accounting systems depend on a nation's educational level. Gernon et al., (1987) contend that there is a positive relationship between educational level and the competence of professional auditors. The lack of professional education and training is often highlighted in reviews of how progress in the accounting and/or auditing field has not materialised (Brody et al., 2005; Al-Awaqleh, 2010; Fraser, 2010). Our argument is that the commitment ISA adoption and harmonisation requires an appreciation of whether there is a sufficient level of competence, both from an academic and a professional standpoint, to be able to understand and apply these standards, together with 
the ability to make professional judgements and process complex information (Zeghal \& Mhedhbi, 2006). Dow \& Karunaratna (2006) argue that the higher the level of education of a country the deeper and larger will be its trade, as a result, of adopting international standards. Parboteeah et al., (2002) compare the national culture of US and Japanese accounting firms and contend that the norms of the accounting profession have a more significant influence on accounting practices than the national cultures of the two countries. Mennicken (2008) also documents the diverse views of audit professionals from the West and Russia who remain divided as to the role of formal education and training in fostering the development of a competent auditing professional. Likewise there are many other studies which provide support for education as a significant determinant in the adoption of international standards (see Guler et al., 2002; Hassan, 2008; Judge et al., 2010). Based on the above, the following hypothesis is presented.

H7: There is a positive relationship between educational attainment of a country and the extent of commitment to ISA adoption and harmonisation.

Nobes (1983) suggests that in addition to social aspects, political factors also impact on accounting and reporting system of a country. He describes the difference between the accounting and reporting systems of socialist, communist and democratic countries but does not provide an empirical validation on the magnitude of the impact of and relationship between the different political regimes/systems on the adoption of ISA. Archambault \& Archambault (2009) did examine the relevance of political systems in explaining IFRS adoption but the results were not significant. There is, therefore, no extant evidence on the effect of 'political institutions'. In this paper we contend that different political regime/system may have a different impact on the adoption of and commitment to ISA, in terms of determining the prevailing political discourse and influence on society. Archambault \& Archambault (2009) argue that a jurisdiction characterised by democratic principles would be more amenable to adopting more stringent rules pertaining to transparency and accountability, such as accounting and auditing standards, with a view to hold powerful forces to account. A degree of relative political freedom enables diverse parties to hold leaders to account. In contrast, countries with political systems with a lower level of civil liberties and more state control are less likely to favour the introduction of auditing standards, particularly if the these standards are designed and controlled by international institutions. We therefore posit the following: 
H8: There is a positive relationship between political regime/system of a country and the extent of commitment to ISA adoption and harmonisation.

\section{Research design \\ Basis of ISA adoption and sampling}

Similar to the case of IFRS (e.g. Ben Othman and Kossentini, 2015), there is no unambiguous authoritative source to draw upon to assess whether (and to what degree) countries have engaged with ISAs. A composite picture can be developed from the IFAC website, the ROSC reports (available on the World Bank website), and regional accounting bodies such as the Federation des Experts-Comptables (Federation of Qualified Accountants, for Europe). In the main, these organisations rely on surveys or episodic country visits to gather evidence on the implementation of ISAs. The main source for our research is IFAC, which surveys its member countries on the level of ISA compliance. According to IFAC's Basis of ISA Adoption by Jurisdiction, (IFAC, 2012), countries are classified in four categories namely: (i) ISAs are required by law as issued by IAASB, (ii) ISAs are adopted by standard setters; (iii) ISAs are adopted with modifications and (iv) 'other'. The last group refers to three different circumstances namely: (i) countries for which available information is not adequate to evaluate whether the local adoption process, including the translation of ISAs into a local language is reasonably up to date with the translation lags of a year; (ii) jurisdictions which indicate that the local generally accepted auditing standards is "based on" or "similar to" the ISAs, but it is unclear whether modifications to, or other differences from, the ISAs meet the requirements of the IAASB Modifications Policy; (iii) Countries which have 'declared' a commitment to convergence with ISAs as an objective but still have some way to go before achieving this objective.

In order to gather more updated information on the fourth category we have perused the SMO Action Plans of IFAC (2009-2015) of each country in order to determine how their ISA 'status' have evolved between 2009 and 2012. While there are some countries that have not adopted ISAs until 2012, a few others have committed to adopt after 2012. An explanatory note is given at the end of Table 2 on countries committed to adopt ISA after 2012. As our study investigates ISA adoption up to 2012, we have considered countries committed to adopt ISA after 2012 as non-adopters for the purpose of our statistical analysis. Drawing from the IFAC classification and how the extent of harmonisation was measured by Ben Othman and Kossentini (2015; refer to Section 4.2.2, p. 79-80) in the case of IFRS, our 
ISA adoption variable is an ordinal variable, reflecting a different extent of commitment to full ISA harmonisation, leading to the following five main groups of countries , namely. 4: ISAs are required by law, 3: ISAs are adopted by national standard setters, 2: ISAs are adopted with modification, 1: others and 0: countries not adopting ISAs. It is important to highlight that this scale does not imply that one country is least or most advanced but rather how each country positions its level of engagement with regards to international harmonization of auditing practices at a point in time. This ordinal scale does not necessarily imply that a country classified as '4' will be more compliant in practice or de facto lead to better audit quality. For instance, according to a ROSC (2012) report for Honduras (classified as '4'), this country needs to make a continued effort to align with international best practice whereas Australia (also a '4') is praised for having incorporated ISAs with some differences into its national standards and/or related other pronouncements (Action Plan, CPA Australia, p. $\left.18^{2}\right)$.

There are forty-eight countries whose status has changed from 2009 to 2012. For example Croatia and Lithuania were classified as ' 1 ' in 2009 but moved to '4' in 2012, Ukraine from ' 1 ' to ' 3 ' and Chile which was in category 2 decided not to adopt ISA in 2012. There are twelve countries that have not adopted ISA by 2012, of which six countries committed to adopt after 2012. These six countries have therefore not adopted ISAs by 2012 and we classified as non-adopters ('0'). Table 2 summarises the status of ISA adoption in 2012 for only eighty-nine countries due to the fact that our empirical analysis focuses on the countries where we have available data with regards to the independent variables.

\section{INSERT TABLE 2 ABOUT HERE}

We then break down the sample into three panels namely: Panel B (77 countries) which excludes non-adopters, Panel C (73 countries) which excludes non-adopters and those committed to adopt ISA after 2012, Panel D (63 countries) which excludes non-adopters, those committed to adopt after 2012 and countries for which information is inadequate. The results of these three Panels are reported in Table 9. There are 72 countries that have adopted Clarity ISAs and the results are reported in Table 10. The distribution of the respective

\footnotetext{
${ }^{2}$ https://www.ifac.org/system/files/complianceassessment/part_3/201403\%20Australia\%20CPA.pdf
} 
samples is reported in Table 2.1 ((refer to sensitivity s analysis for a discussion of the relevant results).

\section{INSERT TABLE 2.1 ABOUT HERE}

\section{Data sources for variables}

In addition to the data sources explained above, this study relies on (1) the Global Competitiveness Reports (2009-2012) by the World Economic Forum (WEF), (2) the World Bank Reports (2002-2010) on the Observance of Standards and Codes (ROSC) for a large number of countries, (3) The World Bank's World Development Indicators, (2009-2012), and (4) the Economic Intelligence Unit Reports (2008-2012)The data is collected for four years 2009 to 2012. These data sources have been relied upon in various economic, management and accounting studies as well as for the preparation of national, regional and international reports e.g. Porter et al., (2005, 2001), Sachs (2003), Blank \& Lopez-Claros (2004) and Houqe et al., (2012). With regards to the WEF dataset, Black and Carnes (2006) use the data to analyse and report the relationship among macroeconomic factors and accounting system whereas Francis et al., (2001) use the dataset to relate investor protection laws, accounting and auditing around the world. Zeghal \& Mhedhbi (2006) use similar databases to investigate the determinants of the adoption of international accounting standards in developing countries whereas Judge et al., (2010) focuses on IFRS adoption globally. Lastly, Boolaky et al., (2013) use the same dataset for 2009 to investigate the determinants of the strength of auditing and reporting standards across the globe.

\section{Variable description}

Extent of ISA Adoption: We define this variable as ISAADOPT and adopt the approach previously described to assess the extent to which a given country commitments to full ISA harmonisation.

The status of "Clarity ISAs" is then considered because it was an important development by IFAC (Humphrey et al., 2009). For this purpose, a dichotomous approach is preferred whereby a country is coded as " 1 " if it has adopted ISA Clarity Standards and " 0 " if not. This is empirically modelled as part of a logistic regression analysis (refer to Table 10). The independent variables used to proxy for the institutional pressures are categorised in terms of the nature of the isomorphism. 
Coercive Isomorphism: There are many variables which can proxy for this factor (e.g. measures concerned with the rule of law, common vs. civil law systems, but as in the case by Judge et al., (2010), not all of them could be included in the analysis due to the potential for high multi-collinearity. For this reason only four variables that have passed the collinearity test have been included in the models. They are depicted below.

Lenders and Borrowers rights (LBRIGHTS): We use the annual legal right index of a country as published in the Global Competitiveness Reports of the World Economic Forum 2009-2012. It represents the degree of legal protection of lenders and borrowers in country and is measured on a scale of $0-10$.

Foreign Aid (FORAID) is sourced from the World Bank Indicators (World Bank 20092012). Drawing from Judge et al., (2010), it is measured as the annual proportion of foreign aid relative to gross domestic product over the period 2009-2012.

Protection of Minority Interest (PMIS): This paper uses the yearly score of the protection of minority interests in a country as published by the Global Competitiveness Reports of the World Economic Forum (2009-2012).

Regulatory Enforcement (REGENF): REGENF is an annual regulatory enforcement index per country and is sourced from the World Justice Project 2009-2012, and it measures the extent to which regulations are fairly and effectively implemented and enforced (The World Justice Project, 2012/3). The Regulatory Enforcement variable is computed using a scale of 0 to 1 where 1 means the highest score and 0 the lowest score. This enforcement index is constructed on the basis of five variables reported by the World Justice Project namely: 1. Government regulations are effectively enforced 2. Government regulations are applied and enforced without improper influence, 3. Administrative proceedings are conducted without unreasonable delay, 4. Due process is respected in administrative proceedings, 5. The Government does not expropriate without adequate compensation.

Mimetic Isomorphism: mimetic isomorphism arises when a corporations in a country mimics the behaviour of another successful corporation(s) /trading partner(s) such as suppliers and foreign companies or foreign owners. There are many variables which would 
fall under the umbrella of mimetic isomorphism, but the presence of high collinearity restrains us to only two of them, namely: import penetration and prevalence of foreign ownership. They are described below.

IMPOPEN is the import penetration and sourced from the World Bank Development Indicators 2009-2012. It is the ratio of import value of commodities sold as a proportion of the gross domestic product for the years 2009-2012. POFO is the annual score on the prevalence of foreign ownership as published by the WEF. This is measured on a scale of 1-7.

Normative Isomorphism: For this study, the proxies for educational attainment (HET) are drawn from the WEF dataset 2009-2012. This is the tertiary enrolment score as published by the WEF during the period 2009-2012. It is expected that countries with a highest score of HET are more exposed to and influenced by professional standards (Judge et al., 2010). Finally we use the Democracy Index published by the Economist Intelligence Unit as proxy for political regime/systems. The Economist Intelligence Unit (ECU) democracy index provides a scale of $0-10$, based on the ratings of 60 indicators grouped into five categories, namely: electoral process and pluralism; civil liberties; the functioning of government; political participation; and political culture. Each category has a rating on a $0-10$ scale and the overall index of democracy is a simple average of the five category indices (EIU, 2012, p.27). The index values are used to place countries within one of four types of regimes ${ }^{\text {vii }}$, i.e. Full democracies (scores 8-10); flawed democracies (scores 6-7.9), hybrid regime (scores 4-5.9) and authoritarian regimes (scores below 4) (EIU, 2012, p. 28)

Control Variables: The predominant role of IOSCO in the IFRS and ISA development agenda (Humphrey et al., 2009; Humphrey \& Loft, 2013; Judge et al., 2010) underlines the importance of capital markets globally as international investors seek to identify opportunities in a number of developed and emerging markets. Needles et al. (2002) mention that capital markets have consistently advocated greater harmony in accounting recognition, measurement and disclosure and in auditing standards to ensure that greater economic efficiencies can be obtained from the operation of global financial centres (2002, p. 185). As mentioned at the outset, greater attention by international agencies on accounting and auditing aspects arose as a result of large investor losses in the emerging markets at the end of the 1990s. This prompted debates worldwide as to the quality and comparability of accounting information to ensure continued confidence in the financial system and the flow 
of investment mainly via capital markets. Hence, principally from an efficiency motive, the extent of ISA adoption may improve the level of investor confidence and may therefore be related to the extent to which capital markets contribute to national economic development. Hence, as in the case of IFRS (Judge et al., 2010, p. 165), one might expect a positive association between the annual market capitalisation MKCAP (as a percentage of gross domestic product from 2009 to 2012) and the country's extent of ISA adoption.

Secondly, the rate of economic growth has been found to be positively correlated with accounting quality (Mueller et al., 2004). Within a capitalist system, the productive sector of the economy relies on the supply of scarce capital resources to industries and firms that have the potential to grow and provide suitable rates of return to equity investors at a given risk level. Accounting information prepared and verified according to auditing standards enables resources to the directed to these more profitable areas of the economy whilst the considering the risk profiles of these investments. Again, from an efficiency perspective, Zeghal \& Mhedhbi (2006) found that economic growth in developing countries has been associated with IFRS adoption. In a similar vein, we therefore expect a positive association between the average rate of economic growth - GDP Growth - (annual growth rate in gross national income from 2009 to 2012) and the extent of ISA adoption. A description of the variables of interests and their association to the various institutional pressures is presented in Table 3.

\section{INSERT TABLE 3 ABOUT HERE}

Lastly, we incorporate other control variables for the sensitivity analysis stage. JUDI is used to measure judicial independence of a country, whilst EOLFW is used to measure the efficiency of legal framework of a country. Furthermore, prior cross-country studies, informed by Hofstede's national culture scores (Ding et al., 2005; Hope et al., 2006; and Clements et al., 2010, among others) suggests that differences in a national culture such as power distance and uncertainty avoidance may influence the commitment to adoption and harmonisation to IFRS . On this basis, we also investigated, as a part of a sensitivity analysis, whether these two cultural scores significantly influence a country's extent of commitment to adopt and seek harmonisation to ISAs and therefore, how would these variables would change the explanatory power of the model. We report the results in Model 15 of Table 11.

Empirical Model 
To evaluate how neo-institutional pressures influence the extent of commitment to ISA adoption and harmonisation at the country level, several regression techniques are employed. The analytical method used to test the hypotheses involves the estimation of the following general form equation for a data set of 89 countries from 2009 to 2012 (356 observations):

Model 1: ISAADOPT $=\beta_{0}+\beta_{1}$ REGENF $+\beta_{2}$ PMIS $+\beta_{3}$ FORAID $+\beta_{4}$ POLSYS $+\beta_{5}$ HET $+\beta_{6}$ LBRIGHTS $+\beta_{7}$ IMPOPEN $+\beta_{8}$ POFO $+\beta_{9}$ GDPGrowth $+\beta 10$ MKCAP

We begin by running the above base regression controlling for GDP growth and market capitalisation using an OLS model. The results are reported in Model 1 of Table 6. In order to determine the robustness of the models, we then compared the results from the pooled regression with the two other regression techniques (multinomial and logistic regressions) in Model $2 \& 3$ respectively of Table 6.

Since the extent of commitment to ISA adoption and harmonisation has more than two categories, a multinomial regression is also justified to investigate the relationship between the dependent and independent variables in order to determine the robustness of this relationship (Judge et al., 2010). Below is the equation for model 2. The results are reported in Table 6 (Model2).

\section{Model 2: $\log (P i j / P i 1)=\beta_{0}+\beta_{1}$ REGENF $+\beta_{2} P M I S+\beta_{3} F O R A I D+\beta_{4} H E T+$ $\beta_{5}$ LBRIGHTS $+\beta_{6} I M P O P E N+\beta_{7}$ POFO $+\beta_{8}$ GDPGrowth $+\beta_{9} \mathrm{MKCAP}+\varepsilon$}

(Pij is the probability that a country chooses one of the 5 categories of ISA adoption basis using one category as a base line or reference; $i$ is the $i$ th individual and $j$ is the $j$ th category of the dependent variable. It is necessary to make one of the categories the baseline category and in this case $(j=1)$.

Relying on Judge et al. (2010), we also re-classify the original five classification of ISA adoption into two binary measures ' 1 ' = ISA is adopted and ' 0 ' ISA is not adopted.) A binary logistic regression is then used to fit the model. The equation for this model is given hereunder. The results are reported in Table 6 (Model 3). A similar approach is used to investigate the drivers of clarity standard ( 72 countries only) and the equation is given at the bottom of Table 10 . 


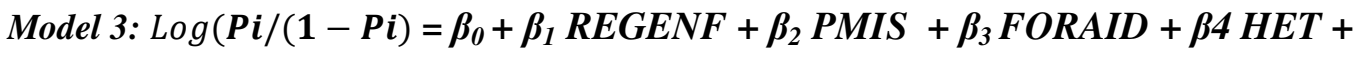
$\beta_{5}$ LBRIGHTS $+\beta_{6} I M P O P E N+\beta_{7}$ POFO $+\beta_{8}$ GDPGrowth $+\beta_{9} \mathrm{MKCAP}+\varepsilon$

$P i$ is the probability of adopting the Clarity ISAs. It is equal to Log (pi/l-pi) where pi = probability of a country adopting ISAs and 1-pi = 1-probability of a country not adopting ISAs.

We subsequently ran two different fixed effects models: (i) Year Fixed Effects with year specific dummy variables controlling mainly for the time period and (ii) Country Fixed Effect with country specific dummy variables. The purpose is to reduce the effects of omitted variable bias and endogeneity. The Year Fixed Effect Model determines the impact of time and Country Fixed Effect Model the impact of country on the ISA commitment and adoption variable. For the country fixed effect regression firstly we have used individual countries as dummies and ran the regression. The results (not reported here) show an Adjusted R square of $77.1 \%$ but with a high level of multi-collinearity. Secondly in order to eliminate the presence of multi-collinearity we reduced the number of dummies by clustering the countries into developed, developing and emerging. The fixed effect equation is provided at the bottom of Table 7. We then report the results in Models $4 \& 5$ to compare with Model 1 in Table 7. Since the political system variable comprises of four different types, we have also dealt with them one at a time to be able to identify the impact of each system on the extent of commitment to ISA adoption and harmonisation. The results are reported in Models 6 to 9 of Table 8.

\section{Results and discussion \\ Descriptive statistics}

We report the descriptive statistics on the variables of interest in Table 4. The mean (median) of ISA adoption (ISAADOP) scaled by category is 1.944 (2.091) respectively. From Table 4, we first note that ISA adoption on a legal basis (law or regulation) is not predominant amongst most countries. This reconciles with column 1 of Table 2 which reported that only 11 countries adopted ISAs in law by the end of 2012. All the countries having done so are developing countries, and are mainly countries from the transitional European region. The second tier relates to the case where ISA has been adopted by the national standard setter and there is in this case a diversity of countries (developed / developing) relying on this level of commitment to ISA harmonisation. A similar diverse constituency can be observed for the third category (ISAs adopted but modified), signalling a 
lower of commitment to global ISA harmonisation. Finally, it is noticeable that the United States has not effectively engaged with ISAs, and we contend that this reflects the relatively unique and dominant role of the country in global economics and politics, thereby making it a rather idiosyncratic case in a study informed by a neo-institutional perspective. The predominance of higher commitment to ISA harmonisation by developing and emerging economies is arguably not surprising in light of the initial concerns arising from the Asian financial crisis and the fact that international agencies and standard-setters have taken particular attention to developing and emerging economies with a bid to 'modernise' the countries' financial architecture(Humphrey et al., 2009).

Regulatory enforcement (REGENF), measured on a scale of $0-1$ has a mean and median of 0.479 and 0.701 respectively, which suggests that regulatory enforcement is on average just below50\%. Protection on minority interest (PMIS), as measured on a scale of 1-7 has a mean of 4.401 with a median of 4.756. Political system (POLSYS) is measured on a scale of 1-10 and reports an average of 6.267 which falls within the band of flawed democracy according to the Economic Intelligence Unit. The tertiary enrolment rate has a mean of 38.56 but reveals a significant variation of 1.932. Lenders and borrowers rights (LBRIGHTS) have a mean of 5.722 on a scale of $0-10$. This implies that $57 \%$ of the countries exercise full lenders and borrowers rights. Import penetration (IMPROPEN) and) have a mean of 41.75 and prevalence of foreign ownership (POFO a mean of 4.946 respectively, measured on a scale from 1 to 7 ).

\section{INSERT TABLE 4 ABOUT HERE}

In order to ensure that our regression results are not unduly influenced by the presence of multi-collinearity, we performed two multi-collinearity tests. First we have computed the Tolerance value ${ }^{\text {viii }}$ and any variable with a value that is less than 0.1 is removed from the model. Second we have counter-checked the Tolerance value by calculating the Variance Inflation Factor (VIF) and any variable greater than 9 is removed from the model (Field, 2000). As a result, we have reduced our set of independent variables excluding the control variables to only eight as follows: four for coercive isomorphism (Regulatory Enforcement, Protection of Minority Interests, Lenders/Borrowers' Rights and Foreign Aid), two for mimetic isomorphism (Import penetration and Prevalence of Foreign Ownership) and two for normative isomorphism (Educational attainment and political system). We have also verified the normality assumptions for all the independent variables and there was no severe issue of 
skewness/kurtosis. Given the size of our sample neither skewness nor kurtosis is expected to have a significant effect on the analysis (Tabachnick \& Fidell, 2007).

We report the mean values (2009-2012) of country-level variables in Table 5. Regulatory enforcement scores are high in Sweden (0.90), Japan (0.80), Denmark (0.85), Austria (0.84) and Australia (0.83). Ukraine (0.2), Zimbabwe (0.1) and Cameron (0.2), Venezuela (0.2), Colombia (0.5) and Bolivia (0.4) are reported as jurisdictions where the enforcement of regulations is weak. Protection of minority interest is stronger in Sweden (6.00), Finland (5.90), South Africa (5.60), and Norway (5.80) whereas Russia (3.20), Ukraine (3.0), Bosnia (2.90) and Kyrgyztan (3.1) have the weakest protection of minority shareholders interest. Countries with high lenders and borrowers' rights' scores are Albania, Australia, Singapore, South Africa, New Zealand, Hong Kong Ukraine, Malaysia and UK but countries such as Malta, Madagascar and Venezuela and Bolivia have the lowest of the average scores on protection of minority interest. Countries with higher import penetration scores (higher that 75\%) are namely: Belgium, Estonia, Hong Kong, Kygyztan, Singapore, and Vietnam but low in Argentina, Bosnia, Colombia, Germany, Japan, Pakistan, Sri Lanka and lowest in Croatia at an average of $7.3 \%$. With regards to the level of higher education, Australia, Denmark, Finland, Greece, Norway, Slovenia, Ukraine and UK have on average a higher tertiary enrolment rate. For the political system, 19 countries have a score of equal to or more than 8 which therefore qualify them as fully democratic countries and 13 countries as classified as autocratic.

\section{INSERT TABLE 5 ABOUT HERE}

\section{Results of empirical models}

\section{Pooled Regression}

We report the results of the statistical models to empirically test the hypotheses (see Table 6, 7, 8, 9, 10 and 11). Table 6 reports the results from three models. Model 1 is the base linear regression. The total variance explained by the model is $21.5 \%$ (Adjusted R Square 0.215). Seven of the eight institutional factors are reported to be statistically positively associated with higher commitment to ISA adoption and harmonisation. All the four coercive pressures are reported to be statistically significant drivers thus supporting Hypotheses 1 to 4 (H1-H4). Lenders and borrowers' rights are reported to be significantly positively related to the dependent variable $(t=7.463, p<.01)$, thus supporting hypothesis (H3). This is reported for the first time in the accounting literature, in contrast to an emphasis on donor country (Judge et al. 2010) and investor protection (La Porta et al., (1998, 2006). Our findings 
suggests that because lenders' rights are arguably more complex than shareholder rights (La Porta et al., 1998), countries may be inclined to signal a higher commitment to ISAs in a bid to enhance the lenders' trust on the quality and reliability of financial statements. Hence, secured creditors (lenders) would appear to signal that the accounts of borrowers need to be audited in line with ISAs.

Foreign aid also reveals a positive significant relationship with the ISA variable $(t=3.821, p$ $<.01$ ), thus supporting hypothesis (H4). Similar to Judge et al., (2010) and Hassan (2008) who found countries which have been funded by the international institutions tend to adopt IFRS, our model also reports that those countries would also signal a greater commitment to full ISA adoption. Regulatory enforcement is significant at $(\mathrm{t}=2.638, \mathrm{p}<.01)$. This supports hypothesis (2). It indicates, ceteris paribus, that countries with stronger regulatory enforcement are more likely to a higher commitment to ISA. For example, Austria, Denmark, Netherlands, Sweden are countries with a high score of regulatory enforcement and have also adopted ISAs. The protection of minority interest is significantly related with ISA $(\mathrm{t}=3.177$, $\mathrm{p}<.01$ ), thus supporting hypothesis $(1)$. Hence, the findings from hypotheses 1 to 4 support the theory that coercive pressures from a combination of resource providers (debt holders, foreign aid) and legal structures (rules and enforcement) leads to a higher extent of commitment to ISA adoption and harmonisation. For example, the majority of countries with a regulatory enforcement scores greater than 0.5 have either adopted ISAs as a basis in law or by standard setters.

With regards to mimetic pressures, only the prevalence of foreign ownership $(t=4.673, p$ $<.01$ ) is found to be a significant determinant of the extent of commitment to ISA adoption and harmonisation, thus supporting hypothesis (5). This result suggests countries that are more opened to foreign corporate ownership are more influenced to seek full harmonisation with international practices (Wei et al. (2001), potentially arising from the use of those standards in other countries. However, contrary to our expectation, import penetration $(\mathrm{t}=.940 ; \mathrm{p}>.10)$ is not significant though positively related to the ISA variable. Hypothesis 6 is not therefore supported. From a theoretical perspective, the dynamics underlying mimetic pressures are quite complex particularly in relation to sovereign nations and political/diplomatic considerations may often outweigh commercial interests to harmonise accounting, auditing and financial practices and thereby do not necessarily lead to similar intentions to commit and adopt particular standards. The influence and power of national 
professional accountancy and auditing bodies may also mediate calls for harmonisation. On a different note, it may also be argued that the selected variable on the import of commodities and as such it may not be able to proxy adequately for mimetic pressures arising from the involvement of foreign participants in the local economy, particularly in terms of investment, and the prominence of financial services.

Both normative pressures are found to be positively associated to the extent of commitment to ISA adoption and. Education is statistically significant $(t=2.011, p<.05)$, thus supporting hypothesis (7). Similar to Zhegal \& Mhdehbi (2006), Brody et al. (2005), Fraser (2010) and Dow \& Karunaratna (2006) our findings confirm that the educational level influences the signal to commit to higher extent of ISA harmonisation. The political system in general is statistically significant $(\mathrm{t}=3.716, \mathrm{p}<.01)$, thus supporting hypothesis $(8)$. Similar to Nobes (1983) and Archambault \& Archambault (2009) who contended that a political system does impact on accounting systems and standards, our result also suggests that the nation's political system or regime has a significant association with the extent of commitment to ISA adoption and harmonisation. However, Archambault \& Archambault (2009) also argue that countries with a lower level of civil liberties and more State control are less likely to favour the introduction of auditing standards. Bearing this in mind, we have unpacked this variable into four sub variables, namely: full democracy, flawed democracy, hybrid regime and autocracy and then investigated which of them is mostly significant. We report and discuss the results in Table 8 .

\section{INSERT TABLE 6 ABOUT HERE}

\section{Fixed Effect Regressions}

We report year fixed effect and country fixed effect regression results in Models $4 \& 5$ of Table 7. The findings suggest that there is no significant time-effect on the extent of commitment to ISA adoption and harmonisation and its determinants. None of the variable of interest has lost significance and all remain significant at least at .05 level. There is also no material change in the magnitude of the coefficients. However, findings from the country fixed effect regression suggest that the country does impact on ISA adoption and its determinants. This is evident when we consider the changes in the significance of the variable of interest in Model 5. Six out of the eight variables of interest have lost significance. They are regulatory enforcement, protection of minority interest, education, foreign aid, import penetration and prevalence of foreign ownership. Weak regulatory enforcement, protection of 
minority interest and relatively low education level are less likely to influence ISA adoption at a country level. Likewise it is less likely that the decision to commit to adopt ISA is low in countries that are more self-dependent (i.e. does not rely too much on imports) and where there is a lack of the presence of foreign corporate bodies or foreign investment. Thirty-nine out of the eighty-nine countries in this study are in the category of developing and emerging markets but have committed highly to ISA either in law, via standard setters or with modifications. From the eleven countries that have adopted ISA in law, 10 are developing and one is an emerging country.

\section{INSERT TABLE 7 ABOUT HERE}

\section{Effects of Political Systems}

We report the impact of the four different political regimes on ISA adoption in Models 6, 7, $8, \& 9$ of Table 8 . The results suggest that both full democratic jurisdiction and a flawed one are equally likely to commit to adopt ISA. The results are reported in Model 6 for full democracy and Model 7 for flawed democracy. Full democracy is significant at $(t=2.486, p$ $<.05)$ and flawed democracy significant at $(t=2.212, p<.05)$, This finding chimes well with Archambault \& Archambault (2009) who contend that democratic jurisdictions are more likely to signal a higher commit to ISA harmonisation and adopt rules pertaining to transparency and accountability, such as accounting and auditing standards, with a view to hold powerful forces to account. Neither the hybrid regime nor the autocratic regime is reported to be statistically significant and they are negatively associated with the ISA variable.

\section{INSERT TABLE 8 ABOUT HERE}

\section{Robustness tests}

To further test for the robustness of the results from Model 1, we use different estimation techniques to investigate the impact of the independent variables on the extent of commitment to ISA adoption and harmonisation and report them in Model 2 and 3 in Table 6. Model 2 is a multinomial regression. All four variables representing coercive pressures (Protection of Minority Interests, Lenders/Borrowers' Rights, Foreign Aid and Regulatory Enforcement) remain statistically significant at a level of at least $(\mathrm{p}<.05)$. With regards to the mimetic pressures, both the prevalence of foreign ownership and import penetration are reported to be statistically significant.at $(\mathrm{p}<.05)$. Similarly, the tertiary education level $(\mathrm{p}<.05)$ and the political system $(\mathrm{p}<.01)$ positively influence the extent of commitment to ISA adoption and harmonisation. Overall, the results from the multinomial regression support our 
prediction about the neo-institutional perspective in terms of how countries commit to ISA adoption. Lastly, model 3 is a binary logistic regression, whereby we re-categorise ISA adoption into a dichotomous variable. Countries that have adopted ISA under any of the first three bases (in law, by standard setters or with modification) are considered as ISA adopters and therefore categorised as " 1 " or " 0 " otherwise. The reason behind this categorisation is that these countries have somehow substantially committed to ISAs as opposed to others who have not or those where the ISA adoption / commitment status is unclear. The results from Model 3 confirm our prior results by also reporting that at least one variable from each of the coercive pressure are statistically significant. However, education, foreign aid and prevalence of foreign ownership have become moderately significant. Lenders/borrowers rights, political system and import penetration are still highly significant at a level of $(\mathrm{p}<.05)$. In conclusion, the tests from the different models still support the main results of the study.

\section{Sensitivity analysis}

In order to extend the robustness tests discussed above, we have conducted a sensitivity analysis using linear regressions for a further seven models (Models 10-16 The results are reported in Table 9, 10 and 11. The results for Panel B are reported in Model 10, Panel C in Model 11 and Panel D in Model 12. Model 13 reports the findings for the adoption of clarity standards. Panel B (Table 2.1, column 2) includes data for four categories of countries (i) ISA adopted in law, (ii) ISA adopted by standard setters, (iii) ISA adopted with modification and (iv) countries for which information are inadequate and excludes non-adopters. Panel $\mathrm{C}$ (Table 2.1, column 3) excludes the sum of Panel B data less number of countries committed to adopt ISA post 2012 and Panel D (Table 2.1, column 4) is the sum of Panel C data, excluding countries with inadequate information. The results for Panel B suggests that three of the coercive pressures are equally significant except foreign aid which is positively but not statistically significantly related with ISA adoption. Both of the normative pressures (political system and education) are equally significant whereas for the mimetic pressures prevalence of foreign ownership remain significant. For Panel C, the significance of the coercive pressures is for all four variables but only the tertiary enrolment rate is reported to be significant as a normative pressure. Again the prevalence of foreign ownership remains a statistically significant determinant of ISA adoption. In the Panel D analysis, the regression reports that all the coercive and normative pressures are significant but the prevalence of 
foreign ownership remains the most prevalent determinant with a moderate level of significance.

\section{INSERT TABLE 9 ABOUT HERE}

Model 13 in Table 10 reports the regression results for ISA adoption. The findings are close to the original findings in Model 1 which suggests that the three types of institutional pressures influence the extent of commitment to ISA adoption and harmonisation.

INSERT TABLE 10 ABOUT HERE

To conclude, Model 14 incorporates two of La Porta et al.'s (2006) variables, namely judicial independence and efficiency of legal framework and Model 15, two Hofstede's (1984) cultural scores namely: power distance and uncertainty avoidance as control variables since previous research has advocated that these may influence accounting standards and practices (Ding et al, 2005; Hope et al., 2006; Clement et al., 2010; Judge et al., 2010). Model 16 incorporates both La Porta et al.'s and Hofstede's variables together. When comparing the results across the three models, it is noted that the effect of the institutional pressures are still present, except for the case of foreign aid being no longer a significant variable. While incorporating La Porta et al.'s (2006) variables, Model 14 in Table 11 suggests that judicial independence and efficiency of legal framework are also not significant determinants of the extent of commitment to ISA adoption and harmonisation. But the other independent variables tested remain significant though at different levels. This suggests that the institutional pressures identified in this study are equally important, particularly in relation to coercive pressures. In Model 15, similar findings are reported but the results also suggest that cultural values/scores of a country do not influence the ISA decision. This is further confirmed in Model 16 from Table 11. This is significant in that Hofstede's cultural dimensions have been extensively relied upon in a number of accounting studies but the use of these dimensions in quantitative research has increasingly been questioned (e.g. Baskerville, 2003).

\section{INSERT TABLE 11 ABOUT HERE}

\section{Conclusion and Implications}

Many countries have been adopting ISAs fully whilst others have been adopting the standards on a partial basis or not at all. The basis upon which ISAs are adopted varies 
considerably between countries and this has been a subject of criticism (Fraser, 2010). From a functionalist perspective, these differences can have important implications for national corporate governance practices and outcomes, multinational corporations, and cross-border investment and trade (Millar et al., 2003; Judge et al., 2010) because ISAs are seen to be an important control mechanism in the production of relevant, reliable and comparable financial statements. From a neo-institutional perspective however, differences in the level of commitment to ISA harmonisation highlight a motivation to study empirically the relevance of national social, political and cultural factors, as initially informed by the existing work on the level of IFRS adoption and harmonisation (e.g. Ben Othman and Kossentini, 2015) and the implementation of corporate governance codes worldwide.

Our findings provide empirical evidence to support our theoretical framework of neoinstitutional pressures on the extent of commitment to ISA adoption and harmonisation. We find that the coercive, mimetic and normative pressures represent significant forces encouraging or impeding ISA harmonisation. In particular, amongst the four coercive-led variables (lenders/borrowers rights, foreign aid, regulatory enforcement, protection of minority interests), the first variable appears to exert a stronger influence on the extent of ISA adoption. Insofar as mimetic isomorphism is concerned, both variables (prevalence of foreign ownership and import penetration) appear to be good predictors for the extent of ISA adoption. Educational attainment, as a normative isomorphism, is also a significant determinant of the commitment to ISA harmonisation similar to the political system. However it is to be noted that for countries with less civil liberties such as autocratic countries and those with a hybrid system, the propensity to commit to full ISA harmonisation is rather low. Moreover,, the results, whilst supporting Simunic et al.'s, (2013) assessment of the drivers of ISA adoption, also show the impact of a number of different social, political and economic factors which were yet to be validated in previous accounting studies, notably in relation to IFRS adoption.

These findings are of relevance to the practitioners and academics currently engaged in the debate how to address cross-country variability in the adoption and implementation of accounting and auditing standards. They are also very important to professional educators to whom the responsibility to provide continuous education and training on ISA has been assigned as per the SMO Action Plan. We argue that prescriptions spearheaded by international agencies (IFAC, IOSCO, World Bank, IMF) to strengthen the national enforcement and regulatory structures for audit practice are often driven by a normative 'logic' (e.g. an independent audit regulator 'ought' to work in all circumstances) and a 'one- 
size fits-all' approach. Our results show that whilst many of the hypothesised institutional factors do matter, it does not mean that the same micro-prescriptions will adequately somehow challenge the institutional structures in the same way and ensure all countries move towards a similar basis of ISA adoption and implementation. For instance, the heightened effect of lenders and borrowers right is notable since most of the mainstream discourse about accounting standards has focused on the implications for equity holders. However, it is arguable that debt holders, particularly in the prevailing context post-financial crisis, have more concerns about the increased risks of relying on financial information deemed to have been audited using the 'best' auditing standards. As also suggested by Humphrey et al., (2009, p. 822), recent criticisms of audit practice in the context of a number of failed financial institutions have raised questions as to the usefulness of the audit process.

Furthermore, the contribution of this study lies in the evidence relating to crosscountry models of commitment to harmonisation of standards, adoption and implementation. The neo-institutional perspective has been gaining ground in the financial accounting arena, specifically in the case of IFRS adoption (Soderstrom \& Sun, 2007; Rahman et al., 2010), as it becomes increasingly clear that the adoption or implementation is not only motivated by the promise of efficiency gains (e.g. lower cost of capital, higher levels of market capitalisation, economic growth) but also by the need to derive legitimacy, such that the organisation, industry or the State can be seen to be worthy of support (e.g.; Judge et al., 2010; Aguilera \& Cuervo-Cazurra, 2004; 2009; Zeghal \& Mhedhbi, 2006; Zattoni \& Cuomo, 2008). Based on the empirical results and their relative robustness and the relatively scarce number of studies on ISA adoption, we recommend further attention on the way ISA implementation is actually supported and enforced by the local audit profession and regulators. In particular, many of these audit regulators have been established in developing countries where the capacity and expertise needed to regulate large accounting firms (e.g. branches of the Big 4 firms) may be insufficient. In effect, even if ISA adoption levels are enhanced, we would argue that additional attention must be paid to the work of the audit regulators and the related enforcement mechanisms.

Notwithstanding the above, the empirical nature of the study implies some limitations. First the data is mainly country-level data and it has been quite difficult to gauge the extent to which particular countries are committed to greater harmonisation with ISAs. The IFAC collected these country-level data through survey/questionnaires and as an example, we question whether the use of the 'other' category is a subtle 'impression management' strategy for countries and IFAC to avoid disclosing an 'official' state of non-compliance. Hence, 
although access to the questionnaires may be possible, the validity and reliability of the data is unknown and only partially validated by the various country ROSC reports. Second there is no publicly available data on the actual use of ISAs by individual audit firms. These limitations do provide directions for future research. To overcome the limitation(s), the adoption and use of ISAs can be investigated using field research, similar to the work undertaken by Mennicken (2008). Finally, close research attention must also be paid to the work carried out by local regulators to understand how (if at all) they ensure that audit firms and auditors actually implement ISAs.

\section{References}

Aguilera, R.V. \& Cuervo-Cazurra, A. (2009), 'Codes of Good Governance', Corporate Governance: An International Review, Vol. 17, No 3, pp. 376-387.

Aguilera, R.V. \& Cuervo-Cazurra, A. (2004), 'Codes of Good Governance Worldwide: What's the Trigger?', Organization Studies, Vol. 25, pp. 417-446.

Al-Awaqleh, Q.A. (2010), 'Factors that influence the Adoption of International Standards on Auditing in Jordan', International Management Review, Vol. 6, No. 2, pp. 28-34.

Archambault, J.J \& Archambault, M.E. (2009), 'An analysis of social factors influencing the adoption of International Financial Reporting Standards', Journal for Global Business Advancement, Vol. 2, No. 2, pp. 38-53

Auditing Practices Board (APB) (2008), Consultation Paper: Consultation on whether UK and Irish Auditing Standards Should be Updated for the New International Auditing Standards, October.

Ball, R. S., Robin, A., \& Wu, J. (2003), 'Incentives versus Standards: Properties of Accounting Income in Four East Asian countries', Journal of Accounting and Economics, Vol. 36, pp. 235-270.

Barth, M. E., Landsman, W. R., Young, D. Q. \& Zhuang, Z. L. (2011), 'Relevance of Differences Between Net Income based on IFRS and Domestic Standards for European firms', International Accounting e-Journal, available at http://papers.ssrn.com/sol3/papers.cfm?abstract_id=1837003, accessed on 18 January 2013.

Baskerville, R.F. (2003), 'Hofstede Never Studied Culture', Accounting, Organizations and Society, Vol. 28, No. 1, pp. 1-14.

Bedard, J. \& Gendron, Y. (2010), 'Strengthening the Financial Reporting System: Can Audit Committees Deliver?', International Journal of Auditing, Vol. 14, No. 2, pp. 174-210. 
Black, E.L., \& Carnes, T.A. (2006), 'Analyst's Forecasts in Asian-Pacific Markets: The Relationship among Macroeconomic factors, Accounting systems, Bias and Accuracy', Journal of International Financial Management and Accounting, Vol. 17, No. 3, pp. 209227.

Blanke, J., \& Lopez-Carlos, C., (2004), 'The Growth Competition Index: Assessing Countries Potential for Sustained Growth', in Porter M.E, Schwabs, K. Sala-Martin X. \& Lopez-Carlos A. (eds), The Global Competitiveness Report 2004-05. New York: Palgrave Macmillan, pp. 3-18.

Boolaky, P.K. (2012), 'Auditing and Reporting in Europe: An Analysis Using Country Level Data', Managerial Auditing Journal, Vol. 27, No. 1, pp. 41-65.

Boolaky, P.K, Krishnamurti, C. \& Hoque, A. (2013), 'Determinants of the Strength of Auditing and Reporting Standards: A Cross-country Study', Australian Accounting and Business Finance Journal, forthcoming.

Brody, R. G., Moscove, S., \& Wnek, R. (2005), 'Auditing standards in Poland: Past, Present and Future', Managerial Auditing Journal, Vol. 20, No. 1, pp. 36-46.

Clements, C.E., Neil, J.D. \& Stovall, S.O., (2010), Cultural Diversity, Country Size, and the IFRS Adoption Decision. [Electronic version]. The Journal of Applied Business Research, 26(2), March/April, 115-126.

Collier, M. W. (2002), 'Explaining Corruption: An Institutional Choice Approach', Crime, Law and Social Change, Vol. 10, pp. 1-31.

Dellaportas, S., Senarath-Yapa, P.W. \& Sivanantham, S. (2008), 'Internationalising Auditing Standards: Stakeholder Views on Australia's Strategic Directions', Managerial Auditing Journal, Vol. 23, No. 7, pp. 663-684.

DiMaggio, P.J \& Powell, W.W. (1983), 'The Iron Cage Revisited: Institutional isomorphism and Collective Rationality in Organisational Fields', American Sociological Review, Vol. 48, No. 2, pp. 147-160.

Ding, Y., Jeanjean, T. \& Stolowy, H. (2005). Why do national GAAP differ from IAS? The role of culture. [Electronic version]. The International Journal of Accounting, 40, 325-350.

Dow, D. \& Karunaratna, A. (2006), 'Developing a Multi-Dimensional Instrument to Measure Psychic Distance Stimuli', Journal of International Business Studies, Vol. 37, pp. 578593.

The Economist : Economic Intelligence Unit Democracy Index 
El-Gazzar, S., Finn, P., \& Jacob, R. (1999), 'An Empirical Investigation of Multinational Firms' Compliance with International Accounting Standards', International Journal of Accounting, Vol. 34, pp. 239-254.

Eden, L., Dacin, T., \& Wan, W. (2001), 'Standards across Borders: Cross Border Diffusion of the Arm's Length Standard in North America', Accounting, Organizations and Society, Vol. 26, pp. 1-20.

Field, A. (2000), Discovering Statistics Using SPSS for Windows, Sage Publications

Flemming, P.D. (1991), 'The Growing Importance of International Accounting Standards', Journal of Accountancy, Vol. 172, pp. 100-105.

Francis, J.R., Khurana, I.K., \& Pereira, R., (2003), 'The Role of Accounting and Auditing in Corporate Governance and the Developments of Financial Markets around the World', Asia-Pacific Journal of Accounting and Economics, Vol. 10, No. 1, pp. 1-30.

Fraser, P.N. (2010), 'A Single Set of Worldwide Auditing Standards: The Road is Long', International Journal of Disclosure and Governance, Vol. 7, pp. 298-309.

Ghafran, C. \& O'Sullivan, N. (2013), 'The Governance Role of Audit Committees: Reviewing a Decade of Evidence', International Journal of Management Reviews, Vol. 15, No. 4, pp. 381-407.

Giacobbe-Miller, J., Miller, D., Zhang, W., \& Victorov, V. (2003), 'Country and Organizational-Level Adaptation to Foreign Workplace Ideologies: A Comparative Study of Distributive Justice Values in China, Russia, and the United States', Journal of International Business Studies, Vol. 34, pp. 389-402.

Gibbs, J. \& Kraemer, K. (2004), 'A Cross-Country Investigation of the Determinants of Scope of E-Commerce Use: An Institutional Approach', Electronic Markets, Vol. 14, pp. 124-144

Gordon, L. A., Loeb, M. P., \& Zhu, W. (2012). 'The impact of IFRS adoption on foreign direct investment', Journal of Accounting and Public Policy, Vol. 31 No. 4, pp. 374-398.

Gray, S.J. (1988), 'Towards a Theory of Cultural Influence on the Development of Accounting Systems Internationally', ABACUS, Vol. 24, No. 1, pp. 1-15.

Guerrreiro, M.S., Rodrigues, L.L. \& Craig, R. (2008), 'The Preparedness of Companies to Adopt International Financial Reporting Standards: Portuguese Evidence', The International Journal of Accounting, Vol. 32, No. 1, pp. 75-88.

Hail, L. \& Leuz, C. (2006), 'International Differences in the Cost of Equity Capital: Do Legal Institutions and Securities Regulation Matter?', Journal of Accounting Research, Vol. 44 No. 5, pp. 485-530. 
Guler, I., Guillen, M. \& Macpherson, J. (2002), 'Global Competition, Institutions and the Diffusion of Organisational Practices: The International Spread of ISO 9000 Quality Certificates', Administrative Science Quarterly, Vol. 47, pp. 207-233.

Hassan, M. (2008), 'The Development of Accounting Regulations in Egypt', Managerial Auditing Journal, Vol. 23, pp. 467-484.

Hofstede, G. (1984), Culture's consequences: International differences in Work Related Values, Beverly Hills, CA.

Hope, O.K., Jin, J. \& Kang, T. (2006). Empirical evidence on jurisdictions that adopt IFRS. Journal of International Accounting Research, 5(2): 1-20.

Houqe, M.N., Van Zijl, T., Dunstan, K., \& Karim, A.K.M.W. (2012), 'The Effect of IFRS Adoption and Investor Protection on Earnings Quality Around the World', International Journal of Accounting, Vol. 47, pp. 333-355.

Humphrey, C. \& Loft, A. (2013), 'Contemporary Audit Regulation - Going Global!', in Caprio Jr., G. (eds), Handbook of Key Global Financial Markets, Institutions, and Infrastructure, Elsevier, Vol. 31, pp. 333-343.

Humphrey, C., Loft, A. \& Woods, M. (2009), 'The Global Audit Profession and the International Financial Architecture: Understanding Regulatory Relationships at a Time of Financial Crisis', Accounting, Organizations and Society, Vol. 34, pp. 810-825.

International Federation of Accountants (IFAC) (2012), Basis of ISA Adoption by Jurisdiction, New York, available at http://www.ifac.org/about-ifac/membership/compliance-program.

Judge, W. Li, S. \& Pinsker, R. (2010), 'National Adoption of International Accounting Standards: An Institutional Perspective', Corporate Governance; An International Review, Vol. 18, No. 1, pp. 161-174.

Kohler, A.G. (2009), Evaluation of the Possible Adoption of International Standards on Auditing (ISAs) in the EU, University of Duisburg-Essen.

Kolk, A. \& Perego, P. (2010), 'Determinants of the Adoption of Sustainability Assurance Statements: An International Investigation', Business, Strategy and the Environment, Vol. 19, pp. 182-198.

Ben Othman, H., \& Kossentini, A. (2015). 'IFRS adoption strategies and theories of economic development: Effects on the development of emerging stock markets'. Journal of Accounting in Emerging Economies, Vol. 5, No. 1, pp. 70-121.

Leuz, C. (2010), 'Different approaches to corporate reporting regulation: how jurisdictions differ and why?', Accounting and Business Research, Vol. 40, No. 3, pp. 229-256. 
Ojo, M. (2010), 'The Role of IASB and Auditing Standards in the Aftermath of the 2008/2009 Financial Crisis', European Law Journal, Vol. 16, No 5, pp. 604-623.

La Porta, R., Lopez-de-Silanes, F., \& Shleifer, A. (2006), 'What Works in Securities Laws?', The Journal of Finance, Vol. 61, pp. 1-32.

Mennicken, A. (2008), 'Connecting Worlds: The Translation of International Auditing Standards into Post-Soviet Audit Practice', Accounting, Organizations and Society, Vol. 33, pp. 384-414.

Meyer, K. \& Nguyen, H. (2001), 'Foreign Investment Strategies and Sub-National Institutions in Emerging Markets: Evidence from Vietnam', Journal of Management Studies, Vol. 42, pp. 63-82.

Meyer, J. \& Rowan, B. (1977), 'Institutionalized Organizations: Formal Structure as Myth and Ceremony', American Journal of Sociology, Vol. 83, pp. 340-363.

Millar, C., Eldomiaty, T., Choi, C., \& Hilton, B. (2005), 'Corporate Governance and Institutional Transparency in Emerging Markets', Journal of Business Ethics, Vol. 59, pp. 163-180.

Needles, B.E., Ramamoorti, S. \& Shelton, S.W. (2002), 'The role of International Auditing in the Improvement of International Financial Reporting', Advances in International Accounting, Vol. 15, pp. 181-201.

Neu, D. \& Ocampo, E. (2007), 'Doing Missionary Work: The World Bank and the Diffusion of Financial Practices', Critical Perspectives on Accounting, Vol. 18, No. 3, pp. 363-389.

Nobes, C.H. (1983), 'A Judgemental International Classification of Financial Reporting Practices', Journal of Business Finance and Accounting, Vol. 10, No. 1, pp. 1-19

Nobes, C.H. (1998), 'Towards a General Model of the Reasons for International Differences in Financial Reporting', ABACUS, Vol. 36, No. 2, pp. 162-187.

Parboteeah, K., Cullen, J., Victor, B., \& Tomoaki, S. (2002), 'National Culture and Ethical Climates: A comparison of U.S. and Japanese Accounting Firms', Management International Review, Vol. 45, pp. 459-480.

Porter, M.E. \& Sakakibara, M., (2001), 'Competing at Home Win Abroad: Evidence from Japanese Industry', Review of Economics and Statistics, Vol. 83, No. 2, pp. 310-322.

Porter, M.E., Schwab, K., \& Lopez-Claros, A., (eds) (2005), The Global Competitiveness Report 2005-06: Policies underpinning Rising Prosperity. New York: Palgrave Macmillan. Radebaugh, L.H. \& Gray, S.J. (1997), International Accounting and Multinational Enterprises, $\left(4^{\text {th }}\right.$ edition) John Wiley $\&$ Sons. 
Rahman, A, Yammeesri, J., \& Perera, H., (2010), 'Financial Reporting Quality in International Settings: A Comparative Study of the USA, Japan, Thailand, France and Germany', International Journal of Accounting, Vol. 45, pp. 1-34.

Rodrigues, L. \& Craig, R. (2006), 'Assessing International Accounting Harmonization using Hegelian Dialetic, Isomorphism, and Foucault', Critical Perspectives in Accounting, Vol. 18, pp. 739-757.

Sachs, J. (2003), 'Institutions Matter, but Not for Everything', Finance and Development, Vol. 40, No. 2, pp. 38-41.

Schockaert, D. \& Houyoux, N. (2007), 'International Standards on Auditing within the European Union', Forum Financier/Revue Bancaire et Financière, Vol. 72, No. 8, pp. 515-529.

Scott, W. R. (2001), Institutions and Organizations, (2nd edition). Thousand Oaks, CA: Sage. The Economist (2012), Democracy Index, Intelligence Unit.

Touron, P. (2005), 'The Adoption of US GAAP by French Firms before the Creation of the International Accounting Standard Committee: An Institutional Explanation', Critical Perspectives on Accounting, Vol. 16, pp. 851-873.

Tuttle, B. \& Dillard, J. (2007), 'Beyond Competition: Institutional Isomorphism in US Accounting Research', Accounting Horizons, Vol. 21, pp. 387-410.

Wei, Y., Liu, X., Song, H., \& Romilly, P. (2001), 'Endogenous Innovation Growth Theory and Regional Income Convergence in China', Journal of International Development, Vol. 13, pp. 153-170.

World Bank, (2002-2008), World Bank Report on Observance of Standards and Codes, available at www.wordlbank.org/ifa/rocs_aa.html .

World Bank Indicators (2009-2012).

( http://databank.worldbank.org/data/reports.aspx?source=world-development-indicators\#)

World Economic Forum (WEF) (2009-2012), Global Competitiveness Reports, New York

World Justice Project Report (2009-2012) www.worldjusticeproject.org

Zeghal, D. \& Mhedhbi, K. (2006), 'An Analysis of the factors affecting the adoption of international accounting standards by developing countries', The International Journal of Accounting, Vol. 41, pp. 373-386.

Zattoni, A. \& Cuomo, F. (2008), 'Why adopt codes of good governance? A comparison of institutional and efficiency perspectives', Corporate Governance: An International Review, Vol. 16, pp. 1-15. 


\begin{abstract}
Website Sources
https://www.ifac.org/about-ifac/membership/compliance-program/compliance-responses.

http://biblioteca.versila.com/14448697/honduras-accounting-and-auditing-informe-sobre-elcumplimiento-de-normas---y-codigos-rosc-contabilidad-y-auditoria
\end{abstract}




\footnotetext{
'international Organisation of Securities' Commissions.
}

ii In 2004 IAASB issued a policy statement 'Clarifying Professional Requirements in International Standards Issued by the IAASB'. That was followed by a Consultation Paper 'Improving the Clarity and Structure of IAASB Standards and related Considerations for Practice Statements'. The ISAs were then put through a "clarification" process and in 2006 the clarity of a number of ISAs (eg. ISAs 240, 330, 315, 600) were completed and named "Clarified ISAs", hence the term 'Clarity Standards'.

iii We acknowledge the suggestion of one of the reviewer with regards to this point.

${ }^{\text {iv }}$ Needles et al., (2002) also documents the early endorsement of ISAs by IOSCO in 1992 but given the latter's continued concerns about the standards and the related standard setting process, this endorsement was allowed to lapse.

v Although one of Humphrey et al.'s (2009) main contentions has been the ability of the major international accounting firms to 'manage' the global auditing standards-setting process.

${ }^{\mathrm{vi}}$ As mentioned by Humphrey et al. (2009, p. 340), it is quite telling and ironic, in the context of the recent financial crisis, that there is no ROSC report on the United States or Iceland.

vii Full democracies: Countries in which not only basic political freedoms and civil liberties are respected, but these will also tend to be underpinned by a political culture conducive to the flourishing of democracy. The functioning of government is satisfactory. Media are independent and diverse. There is an effective system of checks and balances. The judiciary is independent and judicial decisions are enforced. There are only limited problems in the functioning of democracies.

Flawed democracies: These countries also have free and fair elections and even if there are problems (such as infringements on media freedom), basic civil liberties will be respected. However, there are significant weaknesses in other aspects of democracy, including problems in governance, an underdeveloped political culture and low levels of political participation.

Hybrid regimes: Elections have substantial irregularities that often prevent them from being both free and fair. Government pressure on opposition parties and candidates may be common. Serious weaknesses are more prevalent than in flawed democracies--in political culture, functioning of government and political participation. Corruption tends to be widespread and the rule of law is weak. Civil society is weak. Typically there is harassment of and pressure on journalists and the judiciary is not independent.

Authoritarian regimes: In these states state political pluralism is absent or heavily circumscribed. Many countries in this category are outright dictatorships. Some formal institutions of democracy may exist, but these have little substance. Elections, if they do occur, are not free and fair. There is disregard for abuses and infringements of civil liberties. Media are typically state-owned or controlled by groups connected to the ruling regime. There is repression of criticism of the government and pervasive censorship. There is no independent judiciary. (Source: EIU, Democracy Index, 2012, p.28).

${ }^{\text {viii }}$ A Tolerance value less than 0.1 indicates a correlation of 0.9 and a VIF value of greater than 9 also indicates a correlation of 0.9 . This suggests a high incidence of collinearity between the independent variables. 
2

3

4

5

6

7

8

9

10

11

12

13

14

15

16

17

18

19

20

21

22

23

24

25

26

27

28

29

30

31

32

33

34

35

36

37

38

39

40

41

42

43

44

45

46

47

48

49

50

51

52

53

54

55

56

57

58

59

60 


\section{Table 1 (2001-2012): Common Auditing problems based on ROSC reports}

\begin{tabular}{|c|c|}
\hline List of Problems & List of countries (date of ROSC reports) \\
\hline Lack of public oversight of the profession & $\begin{array}{l}\text { Benin (2009), Botswana (2006), Burkina Faso } \\
\text { (2010), Burundi (2007), Ivory Coast (2009), Ethiopia } \\
\text { (2007), The Gambia (2010), Ghana (2004), Kenya } \\
\text { (2010), Madagascar (2008), Malawi (2007), } \\
\text { Mozambique (2008), Uganda (2005), Zambia (2007), } \\
\text { Latvia (2005), Slovakia, Slovenia, Bosnia and } \\
\text { Herzegovina (2004), Hungary (2004), Lithuania } \\
\text { (2007), Bulgaria (2008) }\end{array}$ \\
\hline ISA Translation not equivalent & $\begin{array}{l}\text { Macedonia FYR (2003), Montenegro (2007), Russia, } \\
\text { Slovakia (2001), Slovenia (2004), Serbia (2005), Czec } \\
\text { Republic (2003), Poland (2005) }\end{array}$ \\
\hline Specific ISAs (see note $1 \& 2$ in the Table below) & $\begin{array}{l}\text { Benin(2009), Botswana (2006), Burkina Faso } \\
\text { (2010),Burundi (2007), Ivory Coast (2009), Ethiopia } \\
\text { (2007), The Gambia (2010), Ghana (2004), Kenya } \\
\text { (2010), Madagascar (2008), Malawi (2007), } \\
\text { Mozambique (2008), Uganda (2005), Zambia (2007), } \\
\text { South Africa (2003), Senegal (2005), Latvia, Romania } \\
\text { (2008), Slovakia (2001), Slovenia (2004), Bosnia and } \\
\text { Herzegovina (2004), Serbia (2005), Albania, Poland } \\
\text { (2005), Macedonia FYR (2003), Montenegro (2007), } \\
\text { Turkey (2005), Ukraine (2008) }\end{array}$ \\
\hline Education and Training & $\begin{array}{l}\text { Kenya (2010), Madagascar (2008), Malawi (2007), } \\
\text { Mozambique (2008), Tanzania (2005), Uganda } \\
\text { (2005), Zambia (2007), Latvia (2005), Slovakia } \\
\text { (2001), Bosnia and Herzegovina (2004), Albania } \\
\text { (2006), Lithuania (2002), Macedonia FYR (2003), } \\
\text { Turkey (2005), India (2005). Malaysia (2004), } \\
\text { Pakistan (2005) }\end{array}$ \\
\hline
\end{tabular}

1. ISAs 200, 315, 330,505, 560, 580, 600, 700, 220, 540, 610, 320, 510,100, 120, 260, 505, 710, 540, 550, 620,705 . According to the most recent ROSC reports of the countries in this table, the fore-mentioned ISAs are not complied with. It is also identified that the form and content of audit reports did not comply with relevant ISAs.

2. These countries do not also have a solid quality assurance in place. There is evidence of noncompliance with ISQC 1.

Sources: www worldbank.org/ifa/rosc_aa.html. 
Table 2: Classifying Countries By Basis of ISA Adoption (IAASB pronouncement 2008/9) in 2012*

\begin{tabular}{|c|c|c|c|c|c|}
\hline \multirow{2}{*}{$\begin{array}{l}\text { Required by } \\
\text { Law }\end{array}$} & \multirow{2}{*}{$\begin{array}{l}\text { National Setter } \\
\text { adopts ISAs }\end{array}$} & \multirow{2}{*}{$\begin{array}{l}\text { ISA adopted with } \\
\text { Modifications }\end{array}$} & \multicolumn{3}{|c|}{ 'Others' } \\
\hline & & & $\begin{array}{l}\text { Information } \\
\text { Inadequate }\end{array}$ & $\begin{array}{l}\text { Not Adopted } \\
\text { by } 2012\end{array}$ & $\begin{array}{l}\text { Committed to } \\
\text { Adopt after } 2012 \\
\text { (Note 2) }\end{array}$ \\
\hline Bulgaria (De) & Canada (D) & Albania (De) & Jordan (De) & Italy (D) & Georgia (De) \\
\hline Costa Rica (De) & Czech Rep & Australia (D) & Colombia(E) & $\begin{array}{r}\text { Ivory Coast } \\
(\mathrm{De})\end{array}$ & $\begin{array}{r}\text { Dominican Rep } \\
\text { (De) }\end{array}$ \\
\hline Cyprus(De) & Guatemala & Denmark (D) & $\begin{array}{r}\text { El Salvador } \\
(\mathrm{De})\end{array}$ & Japan (D) & Egypt (E) \\
\hline Estonia(De) & Botswana (De) & $\begin{array}{r}\text { France (note 1) } \\
\text { (D) }\end{array}$ & Indonesia ( E) & Ecuador (De) & Nepal (De) \\
\hline Hungary(E) & Jamaica & $\begin{array}{r}\text { Germany (note } 1) \\
\text { (D) }\end{array}$ & $\begin{array}{r}\text { Kyrgyzstan } \\
(\mathrm{De})\end{array}$ & $\begin{array}{r}\text { Madagascar } \\
(\mathrm{De})\end{array}$ & \\
\hline Malta(De) & Kazakhstan (De) & Hong Kong (D) & Morocco (E) & Peru (E) & \\
\hline Mauritius(De) & Kenya (De) & India ( E) & Nicaragua (De) & $\begin{array}{r}\text { Russian } \\
\text { Federation (E) }\end{array}$ & \\
\hline Romania(De) & Lesotho (De) & Nigeria (De) & Sri Lanka (De) & $\begin{array}{r}\text { Uruguay (D } \\
\mathrm{e}) \\
\end{array}$ & \\
\hline Slovenia(De) & Malawi (De) & Norway (D) & Turkey( E) & $\begin{array}{r}\text { Venezuela } \\
\text { (De) }\end{array}$ & \\
\hline Croatia(De) & Panama & Philippines & UAE (De) & $\begin{array}{r}\text { Netherlands } \\
\text { (D) }\end{array}$ & \\
\hline Mongolia(De) & Serbia (De) & Poland (E) & & $\begin{array}{r}\text { United States } \\
\text { (D) }\end{array}$ & \\
\hline & South Africa (E) & $\begin{array}{r}\text { Portugal (note 1) } \\
\text { (D) }\end{array}$ & & Chile (E) & \\
\hline & $\begin{array}{r}\text { United Kingdom } \\
\text { (D) }\end{array}$ & Singapore(D) & & & \\
\hline & Zambia (De) & Argentina (De) & & & \\
\hline & Zimbabwe (De) & Bolivia (De) & 2 & & \\
\hline & Bangladesh (De) & $\begin{array}{r}\text { Bosnia and } \\
\text { Herzegovina (De) }\end{array}$ & 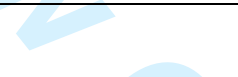 & & \\
\hline & $\begin{array}{r}\text { New Zealand } \\
\text { (D) }\end{array}$ & Cameron (De) & & & \\
\hline & Cambodia (De) & Spain $(\mathrm{D})$ & & & \\
\hline & Ghana (De) & Vietnam (De) & 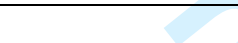 & & \\
\hline & Ukraine (De) & Belgium(D) & & 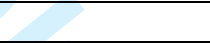 & \\
\hline & Finland (D) & Mexico (E) & & 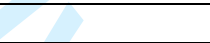 & \\
\hline & Malaysia (E) & China (E) & & 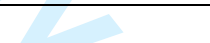 & \\
\hline & Pakistan (De) & & & & \\
\hline & Sweden (D) & & & & \\
\hline & Thailand (E) & & & & \\
\hline & Austria (D) & & & & \\
\hline & Brazil (E) & & & & \\
\hline & Greece (D) & & & & \\
\hline & Uganda (De) & & & & \\
\hline 11 & 29 & 23 & 10 & 12 & 4 \\
\hline
\end{tabular}

Note (1) As per the International Accounting Bulletin (24 April 2015), France, Germany and Portugal are EU countries yet to adopt international auditing standards (ISA). According to a report by the Federation of European Accountants (FEE), in accordance with the EU Audit Directive (which came into force 16 June 2014), the European Commission (EC) was granted the power to impose the use of ISAs for all statutory audits across the EU. For France and Germany, there is a process of transposition into national standards that has been in place for years.

Note (2) Georgia: ISA mandatory from January 2013; Dominican Republic will adopt in 2014; Egypt will not adopt ISA until 2015; Nepal will not adopt until 2014. For the purpose of the statistical analysis, countries committed to adopt after 2012 are considered as non-adopters in 2012. 
* No data available on 37 countries for some of the independent variables despite accessing different sources. For example because some countries do not have a stock exchange we could not obtain data on market capitalisation. Likewise data on cultural scores, regulatory enforcement, lenders and borrowers' rights are not available for all countries We therefore focused on a reduced sample of 89 countries.

(D) = Developed markets; (De) = Developing markets; E = Emerging markets. (Sources: Dow Jones Index and IMF Websites) 
All Countries (note 1)

Countries with available data

Countries with incomplete data

Countries not adopted ISAs (note 2)

Countries committed to adopt after 2012 (note 2)

Countries with inadequate information (note 3 )
126

89
Net sample for analysis (reported in Table 9)

\section{9}

77

(4)

Note (1) These countries are gathered from the IFAC website

Note (2) This information is determined after perusing the SMO Action Plans IFAC reports of each country. These reports can be accessed here https://www.ifac.org/about-ifac/membership/complianceprogram/compliance-responses.

Note (3) Information is not adequate to evaluate whether local adoption process, including ISAs translation into local language is reasonably up to date with translation lags of a year. In other cases where a country indicates that local auditing standards is based on or similar to ISAs, it is not clear whether modifications to or other differences from ISAs meet the IAASB modifications policy 


\begin{tabular}{|c|c|c|c|c|}
\hline \multicolumn{5}{|c|}{ Table 3: Description of Variables } \\
\hline $\begin{array}{l}\text { Dependent } \\
\text { Variable }\end{array}$ & Acronym & Narrative & $\begin{array}{l}\text { Linking Variables } \\
\text { with Isomorphism }\end{array}$ & Sources \\
\hline $\begin{array}{l}\text { Adoption of } \\
\text { International } \\
\text { Standards on } \\
\text { Auditing ) }\end{array}$ & ISAADOPT & $\begin{array}{l}\text { Measures the } \\
\text { adoption on a } \\
\text { multi-nomous } \\
\text { basis. " } 4 \text { " means } \\
\text { that ISA is } \\
\text { mandatory by law, } \\
\text { " } 3 \text { " national } \\
\text { standard setters } \\
\text { have adopted ISA } \\
\text { as auditing } \\
\text { standards but not } \\
\text { mandatory by law, } \\
\text { "2" ISAs have been } \\
\text { generally adopted } \\
\text { as the local auditing } \\
\text { standards but } \\
\text { subject to } \\
\text { modification and } \\
\text { finally when a } \\
\text { country is coded as } \\
\text { " } 1 \text { " it means the } \\
\text { IFAC does not have } \\
\text { adequate } \\
\text { information. } \\
\text { '0' ISA not adopted }\end{array}$ & & $\begin{array}{l}\text { International Federation of } \\
\text { Accountants (www.ifac.org) } \\
\text { https://www.ifac.org/system/files/c } \\
\text { ompliance-assessment/part_3 for } \\
\text { each country }\end{array}$ \\
\hline \multicolumn{5}{|l|}{$\begin{array}{l}\text { Independent } \\
\text { Variables }\end{array}$} \\
\hline $\begin{array}{l}\text { Regulatory } \\
\text { Enforcement }\end{array}$ & REGENF & $\begin{array}{l}\text { Measures of } \\
\text { regulatory } \\
\text { enforcement in a } \\
\text { country and ranges } \\
\text { from } 0 \text { to } 1.0 \\
\text { implies } \\
\text { enforcement is low } \\
\text { and } 1 \text { is high. It is } \\
\text { an average of five } \\
\text { sub-variables }{ }^{\text {ii. }}\end{array}$ & Coercive & $\begin{array}{l}\text { World Justice Project, Rule of Law } \\
\text { Index(worldjusticeproject.org) }\end{array}$ \\
\hline $\begin{array}{l}\text { Protection of } \\
\text { Minority } \\
\text { Interest }\end{array}$ & PMIS & $\begin{array}{l}\text { Measures } \\
\text { protection of } \\
\text { minority } \\
\text { shareholders' } \\
\text { interests on a scale } \\
\text { of } 1 \text { to } 7.1 \text { implies } \\
\text { not protected and } 7 \\
\text { highly protected }\end{array}$ & Coercive & $\begin{array}{l}\text { World Economic Forum, Global } \\
\text { Competitiveness Report (2009- } \\
\text { 2012) www.weforum.org }\end{array}$ \\
\hline Political System & POLSYS & $\begin{array}{l}\text { Measure of the } \\
\text { democracy index } \\
\text { and ranges on a } \\
\text { scale of } 0-10 \text {. Full } \\
\text { democracy }=8- \\
10 \text {, Flawed } \\
\text { democracy } 6 \text { to } 7.9 \text {. } \\
\text { Hybrid }=4 \text { to } 5.9 \text {. }\end{array}$ & Normative & $\begin{array}{l}\text { Economist Intelligence Unit (2009- } \\
\text { 2012) www.eiu.com }\end{array}$ \\
\hline
\end{tabular}




\begin{tabular}{|c|c|c|c|c|}
\hline & & $\begin{array}{l}\text { Autocracy }=0 \text { to } \\
3.9\end{array}$ & & \\
\hline $\begin{array}{l}\text { Higher } \\
\text { Education }\end{array}$ & HET & $\begin{array}{l}\text { Measures tertiary } \\
\text { enrolment score } \\
\text { and ranges from } 1 \\
\text { to } 7.1=\text { lowest } \\
\text { attendance and } 7 \\
\text { highest. }\end{array}$ & Normative & $\begin{array}{l}\text { World Economic Forum (2009- } \\
\text { 2012) }\end{array}$ \\
\hline $\begin{array}{l}\text { Lenders \& } \\
\text { Borrowers } \\
\text { Rights }\end{array}$ & LBRIGHTS & $\begin{array}{l}\text { Measures the } \\
\text { degree of legal } \\
\text { protection of } \\
\text { lenders and } \\
\text { borrowers in a } \\
\text { country and ranges } \\
\text { on a scale of } 0 \text { to } \\
10.0=\text { no } \\
\text { protection and } 10 \\
\text { fully protected. }\end{array}$ & Coercive & $\begin{array}{l}\text { World Economic Forum (2009- } \\
\text { 2012) }\end{array}$ \\
\hline Foreign Aid & FORAID & $\begin{array}{l}\text { Measures } \\
\text { proportion of } \\
\text { foreign aid relative } \\
\text { to gross domestic } \\
\text { product. }\end{array}$ & Coercive & World Bank Indicators (2009-2012) \\
\hline $\begin{array}{l}\text { Import } \\
\text { Penetration }\end{array}$ & IMPOPEN & $\begin{array}{l}\text { It is the ratio of } \\
\text { import value of } \\
\text { commodities sold } \\
\text { as a proportion of } \\
\text { the gross domestic } \\
\text { product. }\end{array}$ & Mimetic & $\begin{array}{l}\text { World Economic Forum (2009- } \\
\text { 2012) }\end{array}$ \\
\hline $\begin{array}{l}\text { Prevalence of } \\
\text { Foreign } \\
\text { Ownership }\end{array}$ & POFO & $\begin{array}{l}\text { Measures the } \\
\text { prevalence of } \\
\text { foreign ownership } \\
\text { on a scale of 1-7. 1 } \\
=\text { no foreign } \\
\text { ownership and } 7= \\
\text { prevalence of } \\
\text { foreign ownership. }\end{array}$ & Mimetic & $\begin{array}{l}\text { World Economic Forum (2009- } \\
\text { 2012) }\end{array}$ \\
\hline $\begin{array}{l}\text { Market } \\
\text { Capitalisation }\end{array}$ & MKCAP & $\begin{array}{l}\text { Measures market } \\
\text { capitalisation as } \\
\text { percentage of gross } \\
\text { domestic product } \\
\text { (Control Variable) } \\
\end{array}$ & & $\begin{array}{l}\text { World Bank Indicators (2009-2012) } \\
\text { data.worldbankorg/indicators }\end{array}$ \\
\hline GDP Growth & GDPGR & $\begin{array}{l}\text { Measures growth } \\
\text { rate in national } \\
\text { income (Control } \\
\text { Variable) }\end{array}$ & & World Bank Indicators (2009-2012) \\
\hline $\begin{array}{l}\text { Judicial } \\
\text { Independence }\end{array}$ & JUDI & $\begin{array}{l}\text { Measure how } \\
\text { independent is the } \\
\text { judiciary of a } \\
\text { country }\end{array}$ & & $\begin{array}{l}\text { La Porta et al (2006) The Journal of } \\
\text { Finance, pp.1-32 }\end{array}$ \\
\hline $\begin{array}{l}\text { Efficiency of } \\
\text { Legal } \\
\text { Framework }\end{array}$ & EOLFW & $\begin{array}{l}\text { Measures the } \\
\text { efficiency of the } \\
\text { legal framework }\end{array}$ & & La Porta et al (2006) \\
\hline Power Distance & PWD & $\begin{array}{l}\text { Measures power } \\
\text { distance in a } \\
\text { country }\end{array}$ & & $\begin{array}{l}\text { Hofstede Cultural Score (1984) } \\
\text { Culture's Consequences: } \\
\text { International Differences in Work } \\
\text { Related values, Beverly Hills, CA }\end{array}$ \\
\hline $\begin{array}{l}\text { Uncertainty } \\
\text { Avoidance }\end{array}$ & UNA & $\begin{array}{l}\text { Measures } \\
\text { uncertainty }\end{array}$ & & Hofstede Cultural score (1984) \\
\hline
\end{tabular}




\begin{tabular}{|l|l|l|l|l|}
\hline & & avoidance & & \\
\hline Political System & POLYS & $\begin{array}{l}\text { Measurement of } \\
\text { Democracy Index }\end{array}$ & & $\begin{array}{l}\text { Economic Intelligence Unit, } \\
\text { Democratic Index report 2012. }\end{array}$ \\
\hline
\end{tabular}


Table 4 Descriptive Statistics $(\mathbf{N}=356)$

\begin{tabular}{|c|c|c|c|c|c|c|}
\hline Variables & Mean & Median & Maximum & Minimum & $\begin{array}{l}\text { Standard } \\
\text { Deviation }\end{array}$ & $\mathbf{N}$ \\
\hline ISAADOP & 1.944 & 2.091 & 4.000 & 1.000 & 0.916 & 356 \\
\hline REGENF & 0.479 & 0.701 & 0.891 & 0.310 & 0.152 & 356 \\
\hline PMIS & 4.401 & 4.756 & 6.000 & 2.800 & .753 & 356 \\
\hline POLSYS* & 6.267 & 1.855 & 9.931 & 2.578 & 1.795 & 356 \\
\hline HET & 38.56 & 26.087 & 40.367 & 22.297 & 1.932 & 356 \\
\hline LBRIGHTS & 5.722 & 2.326 & 10.221 & 1.000 & 2.130 & 356 \\
\hline FORAID & 2.069 & 3.352 & 6.443 & 1.435 & 0.87 & 356 \\
\hline IMPOPEN & 41.750 & 28.934 & 57.012 & 22.622 & 1.106 & 356 \\
\hline POFO & 4.946 & .748 & 6.223 & 3.189 & 0.729 & 356 \\
\hline MKCAP* & 51.918 & 29.751 & 420.900 & 102.310 & 56.132 & 356 \\
\hline GDPGR* & 3.222 & 3.200 & 12.300 & -7.400 & 3.394 & 356 \\
\hline JUDI & 3.950 & 3.701 & 6.712 & 1.590 & 1.354 & 356 \\
\hline EOLFW & 3.637 & 3.600 & 5.670 & 1.600 & 0.948 & 356 \\
\hline PWD & 59.251 & 64.000 & 104.000 & 11.000 & 19.216 & 356 \\
\hline UNA & 67.872 & 69.000 & 112.000 & 13.000 & 23.079 & 356 \\
\hline
\end{tabular}

ISA adoption is the dependent variable. ${ }^{2}$ The dependent variable is recorded in the order of 0 , 1,2,3, and 4. 4= Required by Law or Regulation; $3=$ ISA are adopted by national standard setter; $2=$ ISA partially adopted or modified to meet national needs and $1=$ ISA Inadequate information, $0=$ ISA not adopted by 2012. The independent variables are: Regulatory Enforcement (REGENF), Protection of Minority Interest (PMIS), Educational Attainment (HET), Lenders and Borrowers' Rights (LBRIGHTS), Foreign Aid (FORAID). Import Penetration (IMPOPEN), Political System (POLSYS)* and Prevalence of Foreign Ownership (POFO). All the independent variables relate to the period 2009-2012.

*Political systems include four types namely: Full democracy, flawed democracy, hybrid system and autocracy.

Market Capitalisation as a \% of GDP and GDP growth rate are control variables. 
Table 5: Mean Values of Country Level Variables (Average Score 2009-2012)

\begin{tabular}{|c|c|c|c|c|c|c|c|c|}
\hline Countries & PMIS & REGENF & $\mathrm{HET}^{1}$ & LBRIGHTS & IMPOPEN $^{2}$ & POFO & FORAID $^{3}$ & POLYS \\
\hline Albania & 4.1 & 0.4 & 19.2 & 9.0 & 52.8 & 4.5 & 2.9 & 5.8 \\
\hline Argentina & 3.6 & 0.4 & 66.6 & 3.8 & 15.3 & 5.1 & 0.0 & 6.7 \\
\hline Australia & 5.4 & 0.83 & 75.5 & 9.0 & 21.0 & 5.7 & 0.0 & 9.2 \\
\hline Austria & 5.2 & 0.84 & 52.6 & 6.5 & 49.3 & 5.5 & 0.0 & 8.6 \\
\hline Bangladesh & 3.6 & 0.2 & 7.0 & 7.3 & 26.5 & 4.3 & 1.2 & 5.8 \\
\hline Belgium & 5.1 & 0.3 & 62.8 & 6.5 & 77.3 & 5.9 & 0.0 & 8.1 \\
\hline Bolivia & 3.2 & 0.4 & 39.5 & 1.0 & 35.3 & 3.4 & 3.5 & 6.0 \\
\hline Bosnia and Herzgovina & 2.9 & 0.1 & 33.6 & 5.5 & 14.8 & 4.5 & 3.0 & 5.5 \\
\hline Botswana & 4.8 & 0.2 & 6.4 & 7.0 & 53.5 & 5.5 & 1.3 & 9.7 \\
\hline Brazil & 4.6 & 0.3 & 32.9 & 2.8 & 21.0 & 4.8 & 0.0 & 7.3 \\
\hline Bulgaria & 3.6 & 0.5 & 49.3 & 2.5 & 62.3 & 4.4 & 0.0 & 6.9 \\
\hline Cambodia & 3.9 & 0.1 & 6.0 & 6.3 & 30.8 & 4.7 & 6.7 & 4.9 \\
\hline Cameron & 4.3 & 0.2 & 7.7 & 3.0 & 29.8 & 5.2 & 2.4 & 3.4 \\
\hline Canada & 5.6 & 0.8 & 62.4 & 6.3 & 31.0 & 5.7 & 0.0 & 9.1 \\
\hline Chile & 5.0 & 0.3 & 50.0 & 4.0 & 32.3 & 6.0 & 0.1 & 7.7 \\
\hline China & 4.3 & 0.2 & 22.9 & 3.8 & 30.0 & 4.6 & 0.0 & 3.0 \\
\hline Colombia & 4.2 & 0.5 & 33.8 & 4.3 & 18.3 & 4.7 & 0.3 & 6.5 \\
\hline Costa Rica & 4.5 & $0^{*}$ & 25.3 & 4.75 & 41.64 & 5.75 & .21 & 8.05 \\
\hline Cote D'ivoire & 4.1 & 0.1 & 7.8 & 3.0 & 26.3 & 5.4 & 7.4 & 3.0 \\
\hline Croatia & 3.7 & 0.5 & 46.5 & 6.0 & 7.3 & 4.4 & 0.1 & 7.0 \\
\hline Cyprus & 5.2 & $0^{*}$ & 38.7 & 7.0 & 52.43 & 4.6 & 0 & 7.5 \\
\hline Czech rep & 4.1 & 0.3 & 55.4 & 6.0 & 13.5 & 5.3 & 0.0 & 8.2 \\
\hline Denmark & 5.6 & 0.85 & 79.7 & 8.8 & 40.3 & 5.5 & 0.0 & 9.5 \\
\hline Dominican rep & 3.9 & 0.5 & 33.9 & 3.3 & 40.8 & 5.4 & 6.2 & 6.3 \\
\hline Egypt & 4.5 & 0.1 & 31.6 & 2.5 & 26.8 & 4.7 & 0.4 & 3.9 \\
\hline El Salvador & 4.0 & 0.5 & 22.9 & 4.5 & 20.5 & 5.4 & 1.3 & 6.4 \\
\hline Ecuador & 3.7 & .46 & 34 & 2.5 & 31.05 & 3.85 & .24 & 5.7 \\
\hline Estonia & 4.7 & 0.4 & 64.5 & 5.8 & 76.5 & 5.3 & 0.0 & 7.7 \\
\hline Ethiopia & 4.5 & 0.2 & 3.2 & 4.0 & 30.3 & 3.6 & 10.6 & 4.2 \\
\hline Finland & 5.9 & 0.2 & 94.0 & 6.8 & 38.5 & 5.7 & 0.0 & 9.2 \\
\hline France & 4.9 & 0.7 & 55.3 & 6.8 & 28.3 & 5.7 & 0.0 & 7.9 \\
\hline Georgia & 3.5 & 0.2 & 33.8 & 6.0 & 53.8 & 4.8 & 5.6 & 4.9 \\
\hline Germany & 5.3 & 0.4 & 45.4 & 8.8 & 19.3 & 5.4 & 0.0 & 8.6 \\
\hline Ghana & 4.9 & 0.5 & 5.9 & 6.8 & 44.5 & 5.2 & 5.2 & 5.7 \\
\hline Greece & 4.9 & 0.1 & 92.2 & 3.0 & 31.3 & 4.8 & 0.0 & 8.0 \\
\hline Guatemala & 3.8 & 0.2 & 14.7 & 6.5 & 34.8 & 5.3 & 0.9 & 6.0 \\
\hline Hong Kong SAR & 5.1 & 0.4 & 33.7 & 8.3 & 112.8 & 6.5 & 0.0 & 6.1 \\
\hline Hungary & 4.3 & 0.2 & 67.6 & 6.8 & 80.0 & 5.9 & 0.0 & 7.3 \\
\hline India & 4.8 & 0.4 & 12.4 & 7.5 & 27.0 & 4.8 & 0.2 & 7.6 \\
\hline Indonesia & 4.7 & 0.5 & 18.6 & 3.5 & 23.3 & 5.2 & 0.1 & 6.5 \\
\hline Italy & 3.6 & 0.3 & 67.4 & 3.0 & 26.5 & 4.2 & 0.0 & 7.8 \\
\hline Jamaica & 4.6 & 0.2 & 20.7 & 7.3 & 50.0 & 5.3 & 0.7 & 7.3 \\
\hline Japan & 5.0 & 0.8 & 57.8 & 6.8 & 15.3 & 4.5 & 0.0 & 8.1 \\
\hline
\end{tabular}




\begin{tabular}{|c|c|c|c|c|c|c|c|c|}
\hline Jordan & 5.1 & 0.5 & 39.9 & 4.3 & 69.3 & 5.1 & 3.7 & 3.8 \\
\hline Kazakhstan & 3.7 & 0.2 & 48.4 & 4.8 & 30.0 & 4.2 & 0.2 & 3.3 \\
\hline Kenya & 4.2 & 0.4 & 3.4 & 9.5 & 36.3 & 5.0 & 5.0 & 4.8 \\
\hline Kyrgyz rep & 3.1 & 0.2 & 45.8 & 8.0 & 89.0 & 3.8 & 8.1 & 4.3 \\
\hline Lesotho & 3.6 & $0^{*}$ & 3.6 & 6.5 & 107.7 & 4.95 & 8.5 & 6.36 \\
\hline Macedonia, FYR & 3.8 & 0.1 & 35.2 & 6.8 & 65.3 & 3.9 & 1.9 & 6.2 \\
\hline Madagascar & 3.7 & 0.1 & 3.1 & 1.8 & 48.0 & 4.3 & 4.8 & 4.8 \\
\hline Malawi & 4.7 & 0.1 & 0.2 & 7.5 & 46.5 & 4.9 & 19.5 & 5.5 \\
\hline Malaysia & 5.2 & 0.3 & 30.3 & 9.5 & 72.3 & 5.1 & 0.0 & 6.2 \\
\hline Malta & 5.3 & $0^{*}$ & 31.1 & 2.0 & 84.2 & 5.1 & $0^{*}$ & 8.33 \\
\hline Mauritius & 5.3 & $0^{*}$ & 20.7 & 5.0 & 63.8 & 5.0 & 1.6 & 8.07 \\
\hline Mexico & 4.3 & 0.3 & 26.7 & 4.0 & 32.8 & 5.7 & 0.0 & 6.8 \\
\hline Mongolia & 3.0 & 0.1 & 48.2 & 5.8 & 62.8 & 5.0 & 5.2 & 6.5 \\
\hline Morocco & 4.5 & 0.5 & 11.8 & 3.0 & 44.8 & 4.7 & 1.3 & 3.9 \\
\hline Nepal & 3.7 & 0.1 & 7.5 & 5.0 & 36.0 & 3.2 & 5.1 & 4.0 \\
\hline Netherlands & 5.3 & 0.8 & 60.2 & 6.3 & 69.0 & 5.6 & 0.0 & 4.0 \\
\hline New Zealand & 5.7 & 0.4 & 79.3 & 9.3 & 27.3 & 5.9 & 0.0 & 9.2 \\
\hline Nicaragua & 3.6 & 0.1 & 18.1 & 3.0 & 64.8 & 4.6 & 7.5 & 5.8 \\
\hline Nigeria & 4.1 & 0.5 & 10.2 & 7.8 & 20.0 & 4.9 & 0.6 & 3.6 \\
\hline Norway & 5.8 & 0.4 & 75.6 & 6.8 & 27.8 & 5.5 & 0.0 & 9.7 \\
\hline Pakistan & 4.2 & 0.4 & 4.9 & 5.5 & 19.8 & 4.4 & 1.4 & 4.4 \\
\hline Panama & 4.5 & 0.1 & 45.1 & 6.0 & 51.3 & 5.8 & 0.3 & 7.2 \\
\hline Peru & 4.5 & 0.5 & 34.9 & 6.3 & 22.8 & 5.7 & 0.2 & 6.3 \\
\hline Philippines & 4.3 & 0.5 & 28.6 & 3.0 & 33.5 & 4.5 & 0.1 & 6.3 \\
\hline Poland & 4.4 & 0.6 & 66.5 & 7.5 & 42.5 & 4.9 & 0.0 & 7.2 \\
\hline Portugal & 4.7 & 0.1 & 55.8 & 3.3 & 37.5 & 4.8 & 0.0 & 8.0 \\
\hline Romania & 4.1 & 0.3 & 58.7 & 7.8 & 38.0 & 4.7 & 0.0 & 6.8 \\
\hline Russian federation & 3.2 & 0.2 & 74.7 & 3.0 & 21.5 & 3.6 & 0.0 & 4.4 \\
\hline Serbia & 3.0 & 0.1 & 40.5 & 7.3 & 50.0 & 4.2 & 2.3 & 6.4 \\
\hline Singapore & 5.6 & 0.7 & 58.6 & 9.8 & 181.5 & 6.4 & 0.0 & 5.9 \\
\hline Slovenia & 3.7 & 0.1 & 85.1 & 5.8 & 76.8 & 4.1 & 0.0 & 7.9 \\
\hline South Africa & 5.6 & 0.6 & 15.4 & 8.0 & 29.8 & 5.3 & 0.3 & 7.9 \\
\hline Spain & 4.4 & 0.7 & 69.0 & 6.0 & 27.8 & 5.3 & 0.0 & 8.2 \\
\hline Sri Lanka & 4.8 & 0.1 & 15.1 & 3.8 & 14.8 & 4.9 & 1.1 & 6.4 \\
\hline Sweden & 6.0 & 0.9 & 75.1 & 5.3 & 41.5 & 6.2 & 0.0 & 9.7 \\
\hline Thailand & 4.7 & 0.5 & 46.3 & 4.3 & 63.8 & 4.8 & 0.0 & 6.4 \\
\hline Turkey & 4.0 & 0.5 & 36.4 & 3.8 & 28.5 & 4.9 & 0.3 & 5.7 \\
\hline UAE & 5.0 & 0.3 & 23.8 & 3.8 & 71.0 & 5.1 & 0.0 & 2.5 \\
\hline Uganda & 4.1 & 0.2 & 3.6 & 6.0 & 33.0 & 5.7 & 8.5 & 5.1 \\
\hline UK & 5.3 & 0.4 & 58.6 & 9.3 & 31.8 & 6.1 & 0.0 & 8.2 \\
\hline Ukraine & 3.0 & 0.2 & 76.2 & 8.8 & 52.3 & 3.7 & 0.5 & 6.5 \\
\hline Uruguay & 4.4 & 0.2 & 58.3 & 5.0 & 26.8 & 5.9 & 0.1 & 8.1 \\
\hline US & 5.1 & 0.7 & 82.1 & 7.8 & 15.8 & 5.3 & 0.0 & 8.2 \\
\hline Venezuela & 3.5 & 0.2 & 60.9 & 2.8 & 26.8 & 3.7 & 0.0 & 5.3 \\
\hline Vietnam & 4.3 & 0.2 & 9.5 & 7.3 & 81.0 & 4.2 & 3.0 & 2.8 \\
\hline Zambia & 4.4 & 0.1 & 2.3 & 8.3 & 36.3 & 5.8 & 5.5 & 5.6 \\
\hline
\end{tabular}


Zimbabwe 4.7

0.1

3.7

6.7

60.8

3.9

8.4

2.6 Sources: World Bank Indicators, World Economic Forum, World Justice Project Report, Economic Intelligence Unit Democratic Index. HET $^{1}$ tertiary Education Enrolment Rate; IMPOPEN ${ }^{2}$ Import of goods/services as a percentage of GDP; FORAID ${ }^{3}$ Foreign aid as a percentage GDP

$0^{*}$ no data was available and they are considered ' 0 ' for the purpose of the statistical analysis. 
Table 6 Regression Results using ISA adoption as a Dependent Variable

Panel A: (89 countries including all categories over 4 years)

\begin{tabular}{|c|c|c|c|c|c|c|c|c|c|}
\hline & \multicolumn{3}{|c|}{ Model 1 Linear Regression } & \multicolumn{3}{|c|}{$\begin{array}{l}\text { Model } 2 \text { Multinomial } \\
\text { Regression }^{\mathrm{a}}\end{array}$} & \multicolumn{3}{|c|}{$\begin{array}{c}\text { Model } 3 \text { Binary } \\
\text { Logistic Regression }^{b}\end{array}$} \\
\hline & $\begin{array}{c}\text { Isomorphis } \\
\text { m }\end{array}$ & $\begin{array}{c}\text { Coefficien } \\
t\end{array}$ & t-value & Wald & $\operatorname{Exp}(B)$ & Sig & $\begin{array}{l}\text { Wal } \\
\text { d }\end{array}$ & $\begin{array}{l}\text { Exp } \\
\text { (B) }\end{array}$ & Sig \\
\hline Intercept & & & -.567 & .140 & - & .708 & 1.330 & .299 & .249 \\
\hline REGENF & $\begin{array}{l}\text { Coercive } \\
(\mathrm{H} 2)\end{array}$ & .173 & $\begin{array}{l}2.638 * * \\
*\end{array}$ & 2.531 & 3.017 & $.046 * *$ & 2.329 & .618 & .224 \\
\hline PMIS & $\begin{array}{l}\text { Coercive } \\
\text { (H1) }\end{array}$ & .203 & $\begin{array}{l}3.177 * * \\
*\end{array}$ & 2.964 & 3.934 & $.036 * *$ & .664 & .830 & .415 \\
\hline POLYS & $\begin{array}{l}\text { Normative } \\
\text { (H8) }\end{array}$ & .263 & $\begin{array}{l}3.716^{* *} \\
*\end{array}$ & $\begin{array}{l}16.54 \\
0\end{array}$ & .219 & $\begin{array}{l}.003 * * \\
*\end{array}$ & 5.800 & 2.746 & $\begin{array}{l}.016^{*} \\
*\end{array}$ \\
\hline HET & $\begin{array}{l}\text { Normative } \\
(\mathrm{H} 7)\end{array}$ & .136 & $2.011 * *$ & 2.281 & 1.992 & $.046 * *$ & 1.280 & 1.997 & $.059 *$ \\
\hline $\begin{array}{l}\text { LBRIGHT } \\
\mathrm{S}\end{array}$ & $\begin{array}{l}\text { Coercive } \\
(\mathrm{H} 3)\end{array}$ & .387 & $\begin{array}{l}7.453 * * \\
*\end{array}$ & 3.627 & 1.737 & $.013 * *$ & 4.580 & 1.135 & $\begin{array}{l}.032 * \\
*\end{array}$ \\
\hline FORAID & $\begin{array}{l}\text { Coercive } \\
\text { (H4) }\end{array}$ & .263 & $\begin{array}{l}3.821 * * \\
*\end{array}$ & 2.360 & 1.725 & $.041 * *$ & 1.291 & .657 & $.09 *$ \\
\hline IMPOPEN & Mimetic (H6) & .049 & .940 & 5.074 & 1.675 & $.024 * *$ & 2.722 & 1.118 & $\begin{array}{l}.014^{*} \\
*\end{array}$ \\
\hline POFO & Mimetic (H5) & .281 & $\begin{array}{l}4.673 * * \\
*\end{array}$ & 2.098 & .529 & $.029 * *$ & 3.102 & 1.481 & $.078^{*}$ \\
\hline GDP & & .042 & .731 & .890 & .490 & .109 & 1.008 & .681 & .131 \\
\hline Growth & & & & & & & & & \\
\hline MKCAP & & .057 & .921 & 1.766 & 1.47 & $.031 * *$ & 1.821 & 1.42 & $\begin{array}{l}.041 * \\
*\end{array}$ \\
\hline $\begin{array}{l}\text { Adjusted } \\
\mathrm{R}^{2}\end{array}$ & & & .215 & & .515 & & & .145 & \\
\hline F-Value* & & & 12.248 & & $\begin{array}{l}236.44 \\
3\end{array}$ & & & $\begin{array}{l}37.95 \\
6\end{array}$ & \\
\hline $\mathrm{N}$ & & & 356 & & 356 & & & 356 & \\
\hline
\end{tabular}

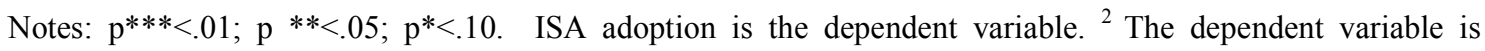
recorded in the order

Of $0,1,2,3$,and 4. 4= Required by Law or Regulation; $3=$ ISA are adopted by national standard setter; $2=$ ISA partially adopted or 
modified to meet national needs, $1=$ "others" i.e. no adequate information is available and ' 0 ' not adopted. $\mathrm{F}$ test for linear regression model and Likelihood ratios for the multinomial and binary regression models. The independent variables are: Regulatory Enforcement (REGENF), Protection of Minority Interest (PMIS), Higher Education enrolment score (HET), Lenders and Borrowers' Rights (LBRIGHTS), Foreign Aid (FORAID). Import Penetration (IMPOPEN) and Prevalence of Foreign Ownership (POFO). GDP Growth sourced from World Bank Indicators, MKCAP-Market Capitalisation also sourced from World Bank Indicators (2009-2012). Political system (POLYS) is sourced from EIU Democratic Index report (2008-2012). For the multinomial regression and binary logistic regression, the Pseudo R square is the Nagelkerke Pseudo R-squared measurement. 
Table 7 Fixed Effect Regression Results using ISA adoption as Dependent Variable

Panel A: (89 countries including all categories over 4 years)

\begin{tabular}{|c|c|c|c|c|c|c|c|}
\hline \multicolumn{4}{|c|}{ Model 1 Pooled Linear Regression } & \multicolumn{2}{|c|}{$\begin{array}{c}\text { Model } 4 \text { Year Fixed } \\
\text { effects }\end{array}$} & \multicolumn{2}{|c|}{$\begin{array}{l}\text { Model } 5 \text { Country } \\
\text { Fixed effects }\end{array}$} \\
\hline & Isomorphism & Coefficient & t-value & Coefficient & t-value & Coefficient & t-value \\
\hline Intercept & & - & -.567 & - & 1.863 & - & .888 \\
\hline REGENF & $\begin{array}{l}\text { Coercive } \\
(\mathrm{H} 2)\end{array}$ & .173 & $2.638 * * *$ & .141 & $2.265 * *$ & .140 & .938 \\
\hline PMIS & $\begin{array}{l}\text { Coercive } \\
\text { (H1) }\end{array}$ & .203 & $3.177 * * *$ & .203 & $3.171 * *$ & .012 & .161 \\
\hline POLYS & Normative & .263 & $3.716^{* * *}$ & .258 & $3.646^{* * *}$ &. .327 & $4.746^{* *}$ \\
\hline HET & $\begin{array}{l}\text { Normative } \\
(\mathrm{H} 7)\end{array}$ & .136 & $2.011 * *$ & .136 & $2.001 * *$ & .030 & .402 \\
\hline LBRIGHTS & $\begin{array}{l}\text { Coercive } \\
\text { (H3) }\end{array}$ & .387 & $7.453 * * *$ & .391 & $.7 .322 * * *$ & .416 & $8.240 * * *$ \\
\hline FORAID & $\begin{array}{l}\text { Coercive } \\
\text { (H4) }\end{array}$ & .263 & $3.821 * * *$ & .161 & $1.863 * *$ & .043 & .719 \\
\hline IMPOPEN & Mimetic (H6) & .049 & .940 & .047 & .895 & .032 & .644 \\
\hline POFO & Mimetic (H5) & .281 & $4.673 * * *$ & .183 & $1784 * *$ & .097 & 1.175 \\
\hline GDP & & .042 & .731 & .051 & .785 & .92 & .604 \\
\hline Growth & & & & & & & \\
\hline MKCAP & & .057 & .921 & .79 & .803 & .78 & .912 \\
\hline Adjusted $\mathrm{R}^{2}$ & & & .215 & & .212 & & .278 \\
\hline F-Value* & & & 12.248 & & 9.654 & & 14.577 \\
\hline $\mathrm{N}$ & & & 356 & & 356 & & 356 \\
\hline
\end{tabular}

This table represents the results of the following of the following regressions:

Model 4: ISAADOP ${ }_{i t}=\beta_{0}+\beta_{1}$ REGENF $_{i t}+\beta_{2}$ PMIS $_{i t}+\beta_{3}$ FORAID $_{i t}+\beta_{4} P_{\text {POLSYS }}+\beta_{5}$ HET $_{i t}+\beta_{6}$ LBRIGHTS $_{i t}+\beta_{7}$ IMPOPEN $_{i t}+\beta_{8}$ POFO $_{i t}+\beta_{9}$ GDPGrowth $_{i t}+\beta 10$ MKCAP $_{i t}+$ Year Fixed Effects

Model 5: ISAADOPT $T_{i t}=\beta_{0}+\beta_{1}$ REGENF $_{i t}+\beta_{2}$ PMIS $_{i t}+\beta_{3}$ FORAID $_{i t}+\beta_{4}$ POLSYS $_{i t}+\beta_{5}$ HET $_{i t}+\beta_{6}$ LBRIGHTS $_{i t}+\beta_{7}$ IMPOPEN $_{i t}+\beta_{8}$ POFO $_{i t}+\beta_{9}$ GDPGrowth $_{i t}+\beta 10 \mathrm{MKCAP}_{i t}+$ Country Fixed Effects

The panel regression s are estimated using (i) pooled regression with no effects, (ii) YEAR fixed effects and (iii) COUNTRY fixed effects. ${ }^{* *}, * *, *$ denote statistical significance at the $1 \%, 5 \%$ and $10 \%$ levels respectively. 
Table 8 Regression Results (Sensitivity Analysis using ISA adoption as Dependent Variable and Separate Democracy Grouping

Panel A: (89 countries including all categories over 4 years)

\begin{tabular}{|c|c|c|c|c|c|c|c|c|c|c|c|}
\hline \multicolumn{4}{|c|}{ Model 1 Pooled Linear Regression } & \multicolumn{2}{|c|}{$\begin{array}{l}\text { Model } 6 \text { Full } \\
\text { Democracy }\end{array}$} & \multicolumn{2}{|c|}{$\begin{array}{c}\text { Model } 7 \text { Flawed } \\
\text { Democracy }\end{array}$} & \multicolumn{2}{|c|}{ Model 8 Hybrid } & \multicolumn{2}{|c|}{ Model 9 Autocracy } \\
\hline & Isomorphism & Coefficient & t-value & Coefficient & t-value & Coefficient & t-value & Coefficient & t-value & Coefficient & t-value \\
\hline REGENF & $\begin{array}{l}\text { Coercive } \\
(\mathrm{H} 2)\end{array}$ & .173 & $2.638^{* * *}$ & .176 & $2.932 * *$ & .173 & $2.638 * *$ & .173 & $2.638 * *$ & .173 & $2.638 * *$ \\
\hline POLYS & Normative & .263 & $3.716^{* * *}$ & .134 & $2.486 * *$ & .114 & $2.212 * *$ & .081 & 1.475 & -.050 & -.921 \\
\hline HET & $\begin{array}{l}\text { Normative } \\
\text { (H7) }\end{array}$ & .136 & $2.011 * *$ & .138 & $2.151 * *$ & .136 & $2.011 * *$ & .136 & $2.011 * *$ & .136 & $2.011 * *$ \\
\hline LBRIGHTS & $\begin{array}{l}\text { Coercive } \\
\text { (H3) }\end{array}$ & .387 & $7.453 * * *$ & .441 & $8.379 * * *$ & .437 & $8.580 * * *$ & .442 & $8.611^{* * *}$ & .422 & $7.956^{* * *}$ \\
\hline IMPOPEN & Mimetic (H6) & .049 & .940 & .046 & .456 & .046 & .940 & .046 & .940 & .010 & .200 \\
\hline POFO & Mimetic (H5) & .281 & $4.673 * * *$ & .145 & $2.234 * *$ & .163 & $1.917 * *$ & .138 & $2.137 * *$ & .130 & $1.951 * *$ \\
\hline GDP & & .042 & .731 & .42 & .731 & .42 & .731 & .42 & .731 & .42 & .731 \\
\hline Growth & & & & & & & & & & & \\
\hline MKCAP & & .057 & .921 & .057 & .921 & .057 & .921 & .057 & .921 & .057 & .921 \\
\hline Adjusted $\mathrm{R}^{2}$ & & & .215 & & .184 & & .195 & & .189 & & .186 \\
\hline F-Value* & & & 12.248 & & 10.943 & & 11.074 & & 11.278 & & 11.070 \\
\hline $\mathrm{N}$ & & & 356 & & 356 & & 356 & & 356 & & 356 \\
\hline
\end{tabular}


This table represents the results of the following of the following regressions:

Model 6: ISAADOPT $=\beta_{0}+\beta_{1}$ REGENF $+\beta_{2}$ PMIS $+\beta_{3}$ FORAID $+\beta_{4} F D+\beta_{5}$ HET $+\beta_{6}$ LBRIGHTS $+\beta_{7} I M P O P E N+\beta_{8}$ POFO $+\beta_{9}$ GDPGrowth $+\beta 10 \mathrm{MKCAP}+\mathrm{e}$ Model 7: ISAADOPT $=\beta_{0}+\beta_{1}$ REGENF $+\beta_{2}$ PMIS $+\beta_{3} F O R A I D+\beta_{4} F L D+\beta_{5}$ HET $+\beta_{6}$ LBRIGHTS $+\beta_{7} I M P O P E N+\beta_{8}$ POFO $+\beta_{9}$ GDPGrowth $+\beta 10$ MKCAP $+\mathrm{e}$ Model 8: ISAADOPT $=\beta_{0}+\beta_{1}$ REGENF $+\beta_{2}$ PMIS $+\beta_{3}$ FORAID $+\beta_{4} H B S+\beta_{5}$ HET $+\beta_{6}$ LBRIGHTS $+\beta_{7}$ IMPOPEN $+\beta_{8}$ POFO $+\beta_{9}$ GDPGrowth $+\beta 10$ MKCAP $+\mathrm{e}$ MOdel 9: ISAADOPT $=\beta_{0}+\beta_{1}$ REGENF $+\beta_{2}$ PMIS $+\beta_{3}$ FORAID $+\beta_{4} A C+\beta_{5}$ HET $+\beta_{6}$ LBRIGHTS $+\beta_{7} I M P O P E N+\beta_{8}$ POFO $+\beta_{9}$ GDPGrowth $+\beta 10 \mathrm{MKCAP}+\mathrm{e}$ The panel regressions are estimated using (i) pooled regression with (i) full democracy, (ii) flawed democracy and (iii) hybrid system and (iv) autocracy as measured and classified by the Economic Intelligence Unit. $* * * * *, *$ denote statistical significance at the $1 \%, 5 \%$ and $10 \%$ levels respectively. 
Table 9 Regression Results Sensitivity Analysis using ISA adoption as Dependent Panel A -D

\begin{tabular}{|c|c|c|c|c|c|c|c|c|c|}
\hline \multicolumn{4}{|c|}{ Model 1 Pooled Linear Regression } & \multicolumn{2}{|c|}{ Model 10 (Panel B) $^{1}$} & \multicolumn{2}{|c|}{ Model 11 (Panel C) $^{2}$} & \multicolumn{2}{|c|}{ Model 12 (Panel D) $^{3}$} \\
\hline & Isomorphism & Coefficient & t-value & Coefficient & t-value & Coefficient & t-value & Coefficient & t-value \\
\hline Intercept & & - & -.567 & - & 3.252 & & 4.400 & & 6.086 \\
\hline REGENF & $\begin{array}{l}\text { Coercive } \\
(\mathrm{H} 2)\end{array}$ & .173 & $2.638 * * *$ & .118 & $2.731 * *$ & .117 & $2.118 * *$ & .137 & $2.987 * *$ \\
\hline PMIS & $\begin{array}{l}\text { Coercive } \\
(\mathrm{H} 1)\end{array}$ & .203 & $3.177 * * *$ & .239 & $3.617 * * *$ & .198 & $2.829^{* *}$ & .291 & $3.736^{* *}$ \\
\hline POLYS & Normative & .263 & $3.716^{* * *}$ & .241 & $3.059^{* *}$ & .236 & 2.882 & .253 & $2.715^{* *}$ \\
\hline HET & $\begin{array}{l}\text { Normative } \\
\text { (H7) }\end{array}$ & .136 & $2.011^{* *}$ & .114 & $2.069 * *$ & .135 & $2.987 * *$ & .142 & $2.683^{* *}$ \\
\hline LBRIGHTS & $\begin{array}{l}\text { Coercive } \\
(\mathrm{H} 3)\end{array}$ & .387 & $7.453 * * *$ & .413 & $7.611 * * *$ & .417 & $7.389 * * *$ & .373 & $6.005 * * *$ \\
\hline FORAID & $\begin{array}{l}\text { Coercive } \\
(\mathrm{H} 4)\end{array}$ & .263 & $3.821 * * *$ & .062 & 1.025 & .140 & $2.891^{* *}$ & .161 & $2.916^{* *}$ \\
\hline IMPOPEN & Mimetic (H6) & .049 & .940 & .022 & .983 & .040 & 1.013 & .045 & .696 \\
\hline POFO & Mimetic (H5) & .281 & $4.673 * * *$ & .133 & $2.781 * *$ & .136 & $2.813 * *$ & .149 & $2.596 * *$ \\
\hline GDP & & .042 & .731 & .051 & .674 & .059 & .681 & .079 & .812 \\
\hline Growth & & & & & & & & & \\
\hline MKCAP & & .057 & .921 & .063 & .967 & .058 & .786 & .081 & 1.013 \\
\hline Adjusted $\mathrm{R}^{2}$ & & & .215 & & .242 & & .219 & & .181 \\
\hline F-Value* & & & 12.248 & & 13.181 & & 11.101 & & 7.879 \\
\hline $\mathrm{N}$ & & & 356 & & 308 & & 292 & & 252 \\
\hline
\end{tabular}

This table represents the results of the following of the following regressions:

Models 10-12:ISAADOPT $=\beta_{0}+\beta_{1}$ REGENF $+\beta_{2}$ PMIS $+\beta_{3}$ FORAID $+\beta_{4}$ POLYS $+\beta_{5}$ HET $+\beta_{6}$ LBRIGHTS $+\beta_{7} I M P O P E N+\beta_{8}$ POFO $+\beta_{9}$ GDPGrowth $+\beta 10$ $\mathrm{MKCAP}+\mathrm{e}$ 
${ }^{2}$ Model 10 Panel B excludes countries that have not adopted ISAs.

${ }^{2}$ Model11 Panel C excludes both countries that have not adopted and committed to adopt after 2012.

${ }^{3}$ Model 12 Panel D includes only ISA adopted in law, by standards setters and with modification.

The panel regressions are estimated using (i) pooled regression with (i) full democracy, (ii) flawed democracy and (iii) hybrid system and (iv) autocracy as measured and classified by the Economic Intelligence Unit. $* * * * *, *$ denote statistical significance at the $1 \%, 5 \%$ and $10 \%$ levels respectively. 
Table 10: Model 13 Linear Regression for Adoption of Clarity Standards

\begin{tabular}{llll}
\hline & Isomorphism & Coefficient & t-value \\
\hline Intercept & & -.567 \\
REGENF & Coercive (H2) & .189 & $3.723^{* * *}$ \\
PMIS & Coercive (H1) & .197 & $2.645^{* * *}$ \\
POLYS & Normative & .248 & $3.237^{* * *}$ \\
HET & Normative (H7) & .748 & $1.932^{* *}$ \\
LBRIGHTS & Coercive (H3) & .296 & $5.731^{* * *}$ \\
FORAID & Coercive (H4) & .198 & $2.998^{* * *}$ \\
IMPOPEN & Mimetic (H6) & .068 & .893 \\
POFO & Mimetic (H5) & .301 & $4.784^{* * *}$ \\
GDP Growth & & .042 & .731 \\
MKCAP & & .057 & .921 \\
Adjusted R & & & .189 \\
F-Value* & & & 13.182 \\
$\mathrm{~N}$ & & & 288 \\
\hline Only 72 countries adopted ISA clarity standards. *** Significant at .001 level, ** significant at .05 level.
\end{tabular}

Only 72 countries adopted ISA clarity standards. ${ }^{* * *}$ Significant at .001 level, ${ }^{* *}$ significant at .05 level.

The regression is run using the following equation:

$\log \left(P i /(1-P i)=\beta_{0}+\beta_{1}\right.$ REGENF $+\beta_{2}$ PMIS $+\beta_{3}$ FORAID $+\beta 4$ HET $+\beta_{5}$ LBRIGHTS $+\beta_{6}$ IMPOPEN + $\beta_{7} \mathrm{POFO}+\beta_{8}$ GDPGrowth $+\beta_{9} \mathrm{MKCAP}+\varepsilon$

$P i$ is the probability of adopting the Clarity ISAs. It is equal to Log (pi/1-pi) where pi = probability of a country adopting ISAs and 1-pi $=1$ - probability of a country not adopting ISAs. 
Table 11 Linear Regression Sensitivity Analysis (With Hofstede Cultural Score and La Porta Legal Variables)

\begin{tabular}{|c|c|c|c|c|c|c|c|}
\hline \multicolumn{4}{|c|}{ Model 14 (Including 2 Variables from La Porta) } & \multicolumn{2}{|c|}{$\begin{array}{l}\text { Model } 15 \text { (Including } 2 \\
\text { cultural scores) }\end{array}$} & \multicolumn{2}{|c|}{$\begin{array}{l}\text { Model } 16 \text { (La Porta \& } \\
\text { Culture) }\end{array}$} \\
\hline Variables & $\begin{array}{c}\text { Isomorphis } \\
\text { m }\end{array}$ & $\begin{array}{c}\text { Coefficien } \\
t\end{array}$ & t-value & $\begin{array}{c}\text { Coefficien } \\
t\end{array}$ & t-value & $\begin{array}{c}\text { Coefficien } \\
t\end{array}$ & t-value \\
\hline Intercept & & & -.208 & & -.227 & & -.193 \\
\hline REGENF & Coercive & .191 & $1.347^{*}$ & .351 & $2.673^{* *}$ & .251 & $1.123 *$ \\
\hline PMIS & Coercive & .263 & $2.115^{* *}$ & .167 & $1.832 *$ & .124 & $1.673^{*}$ \\
\hline HET & Normative & .217 & $1.578^{*}$ & .123 & $1.044^{*}$ & .087 & .411 \\
\hline POLYS & Normative & .238 & $2.428 * *$ & .197 & $1.876^{*}$ & .183 & $1.673^{*}$ \\
\hline LBRIGHTS & Coercive & .468 & $3.980 * * *$ & .459 & $4.167 * * *$ & .398 & $3.392 * * *$ \\
\hline FORAID & Coercive & .098 & .973 & .108 & 1.134 & .103 & 1.004 \\
\hline IMPOPEN & Mimetic & -.235 & -.984 & .197 & .546 & -.042 & -.701 \\
\hline POFO & Mimetic & .163 & $2.009 * *$ & .127 & $2.481^{* *}$ & .254 & $1.753^{*}$ \\
\hline GDP & & -.008 & .060 & .081 & .596 & -.054 & -.383 \\
\hline \multicolumn{8}{|l|}{ Growth } \\
\hline MKCAP & & .034 & .233 & -.015 & -.100 & .004 & .028 \\
\hline JUDI & & .091 & .507 & & & .228 & .768 \\
\hline EOLFW & & .193 & .486 & & & -.207 & -.773 \\
\hline PWD & & & & .126 & .872 & .191 & 1.082 \\
\hline UAV & & & & -.001 & -.007 & -.022 & -.167 \\
\hline Adjusted $\mathrm{R}^{2}$ & & & .213 & & .236 & & .201 \\
\hline F-Value* & & & 13.651 & & 14.669 & & 12.205 \\
\hline $\mathrm{N}$ & & & 288 & & 288 & & 288 \\
\hline
\end{tabular}

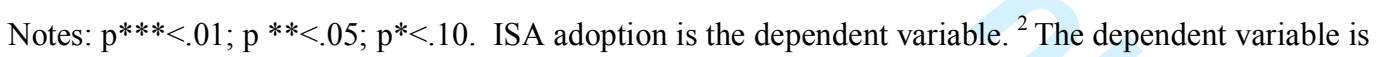
recorded in the order of $0,1,2,3$, and 4 .

$4=$ Required by Law or Regulation; 3 = ISA are adopted by national standard setter; 2 = ISA partially adopted or modified to meet national needs and 1 = “others", ' 0 ' not adopted. The independent variables are: Regulatory Enforcement (REGENF), Protection of Minority Interest (PMIS), Educational Attainment (HET), Lenders and Borrowers' Rights (LBRIGHTS), Foreign Aid (FORAID). Import Penetration (IMPOPEN) and Prevalence of Foreign Ownership, JUDI (Judicial Independence), EOLFW (Efficiency of Legal Framework), PWD (Power Distance) UAV (uncertainty Avoidance) Political System (POLYS) 